\title{
Exploring the Composition of Lithic Assemblages in Mesolithic South-Eastern Norway
}

\author{
Isak Roalkvam ${ }^{1}$
}

19 February, 2022

\begin{abstract}
This paper leverages multivariate statistics to explore the composition of 54 Mesolithic assemblages located in south-eastern Norway. To provide analytical control pertaining to factors such as variable excavation practices, systems for artefact categorisation and raw-material availability, the sites chosen for analysis have all been excavated relatively recently and have a constrained geographical distribution. The assemblages were explored following two strains of analysis. The first of these entailed the use of artefact categories that are in established use within Norwegian Mesolithic archaeology, while the other involved drawing on measures that have been linked directly to land-use and mobility patterns associated with lithic assemblages more widely. The findings pertaining to the established artefact categories largely reflect the temporal development previously reported in Norwegian Mesolithic research. Furthermore, the chronological trends associated with variables taken from the so-called Whole Assemblage Behavioural Indicators (e.g. Clark and Barton 2017), originally devised for characterising Palaeolithic assemblages in terms of associated mobility patterns, also align with the development previously proposed in the literature. This provides an initial indication that these measures are applicable in a Norwegian Mesolithic setting as well, setting the stage for a more targeted and rigorous model evaluation outside this exploratory setting. Furthermore, this finding supports the notion that these measures can offer a powerful comparative tool in the analysis of lithic assemblages more generally.

${ }^{1}$ University of Oslo, Department of Archaeology, Conservation and History
\end{abstract}

\section{Highlights}

- Multivariate exploratory analysis of Mesolithic assemblages in south-eastern Norway

- Explores patterns related to established artefact categories in Norwegian archaeology

- Explores variables associated with mobility patterns in lithic assemblage studies

- Draws on the Whole Assemblage Behavioural Indicators (WABI)

- Relevance for Mesolithic Norway supports the notion that WABI are widely applicable

Keywords: Mesolithic Scandinavia; Multivariate statistics; Mobility strategies; Whole Assemblage Behavioural Indicators

\section{Introduction}

This study employs multivariate exploratory statistics to analyse lithic assemblages associated with Mesolithic sites located in south-eastern Norway. This is done to identify latent patterns and structure in the relationship between the assemblages, with the ultimate aim of identifying behaviourally induced variation in their composition across time. However, the composition of the assemblages can be expected to be determined by a multitude of factors (e.g. Dibble et al. 2017; Rezek et al. 2020), ranging from the impact of natural formation processes, to various and intermixed behavioural aspects such as purpose, duration, frequency and group sizes at visits to the sites. The assemblages are also likely to be impacted by variation in lithic technology, 
artefact function, use-life and discard patterns, as well as procurement strategies and access to raw materials. Finally, analytic and methodological dimensions relating to survey, excavation and classification practices are also fundamental to how the assemblages are defined. Consequently, the analysis conducted here is done from an exploratory perspective, where all of these factors should be seen as potential contributors to any observed pattern. In an attempt to limit the influence of some potentially confounding effects, the material chosen for analysis has a constrained geographical distribution, and stems from recent investigations that have employed comparable methods for excavation and classification within larger unified projects.

Even though each individual assemblage can have been impacted by an virtual infinitude of effects that might skew an archaeological interpretation, this does not preclude the applicability of inductive analyses aimed at revealing overarching structure in the data without imposing overly complex analytical frameworks that attempt to account for these particularities (Bevan 2015). Structure that can be revealed from considering all of the assemblages in aggregate can constitute a step in an iterative analytical chain that ultimately aims to tease apart the multitude of factors that have shaped the composition of the assemblages. This would in turn give analytical access to the organisation of lithic technology and variation in past behaviour, adaptation and demographic development (see for example Andrefsky 2009; Barton et al. 2011; Binford 1979; Dibble et al. 2017; Rezek et al. 2020). The most immediate danger of the approach outlined here is rather to be overly naive in the causal significance and cultural importance that is ascribed to any identified pattern. As such, the main aim of this analysis is to compare the results with findings reported in previous literature concerned with the Mesolithic in southern Norway and have the generation of new hypotheses as a possible outcome. To this end, the analysis follows two analytical avenues. The first involves an analysis of the assemblages using the classification of the artefacts done for the original excavation reports. The second involves an analysis of the assemblages in light of the so-called Whole Assemblage Behavioural Indicators (e.g. Clark and Barton 2017) and other factors that have been employed to align properties of lithic assemblages with land-use and mobility patterns.

\section{Archaeological context and material}

The Early Mesolithic, or Flake Axe Phase, is defined as lasting from c. 9300-8200 BCE (Table 2), and is set to start with the first recorded human presence in Norway (Damlien and Solheim 2018). Previous research has typically proposed that the Early Mesolithic is characterised by a relatively high degree of mobility, and low variation in site types and associated mobility patterns (e.g. Bjerck 2008; Breivik and Callanan 2016; Fuglestvedt 2012; Nærøy 2018; but see Åstveit 2014; Viken 2018). Around the transition to the subsequent Middle Mesolithic or Microlith Phase at c. 8200 BCE, pervasive changes in blade and axe technology occur (Damlien 2016; Eymundsson et al. 2018; Solheim et al. 2020), which in turn has been associated with changes in population genomics and related migration events hailing from the Eurasian steppes (Günther et al. 2018; Manninen et al. 2021). The Microlith Phase is defined as lasting until around $7000 \mathrm{BCE}$, which is followed by the Pecked Adze Phase, characterised by a more dominating presence of non-flint macro tools and associated production waste in the assemblages (Reitan 2016). The next typological transition at c. 5600 BCE signifies the onset of the Nøstvet Adze Phase. While previously defined as having a slightly longer duration, the Nøstvet Phase has traditionally been seen as representing the onset of more varied settlement systems and stable mobility patterns (e.g. Jaksland 2001; Lindblom 1984). In recent years it has been suggested that the transition to a decrease in mobility and more varied land-use patterns can be traced back to the Middle Mesolithic (Solheim and Persson 2016). The subsequent Transverse Arrowhead Phase (c. 4500-3900 BCE) is characterised by a dramatic decrease in axe finds, and the introduction of new flint projectiles (Reitan 2016). It has recently been suggested that a dispersal of people from southern Scandinavia into southern Norway takes place in this period (Eigeland 2015:379; Nielsen 2021), which could follow after a preceding population decline at c. 4300 BCE (Nielsen 2021; cf. Solheim 2020; Solheim and Persson 2018).

A defining characteristic of the Norwegian Mesolithic is that a clear majority of the known sites are located in coastal areas (e.g. Bjerck 2008). Furthermore, these coastal sites appear to predominantly have been located on or close to the contemporary shoreline when they were in use (Åstveit 2018; Breivik et al. 2018; Møller 1987; Solheim 2020). In south-eastern Norway, this pattern is combined with a continuous regression 


\section{A}
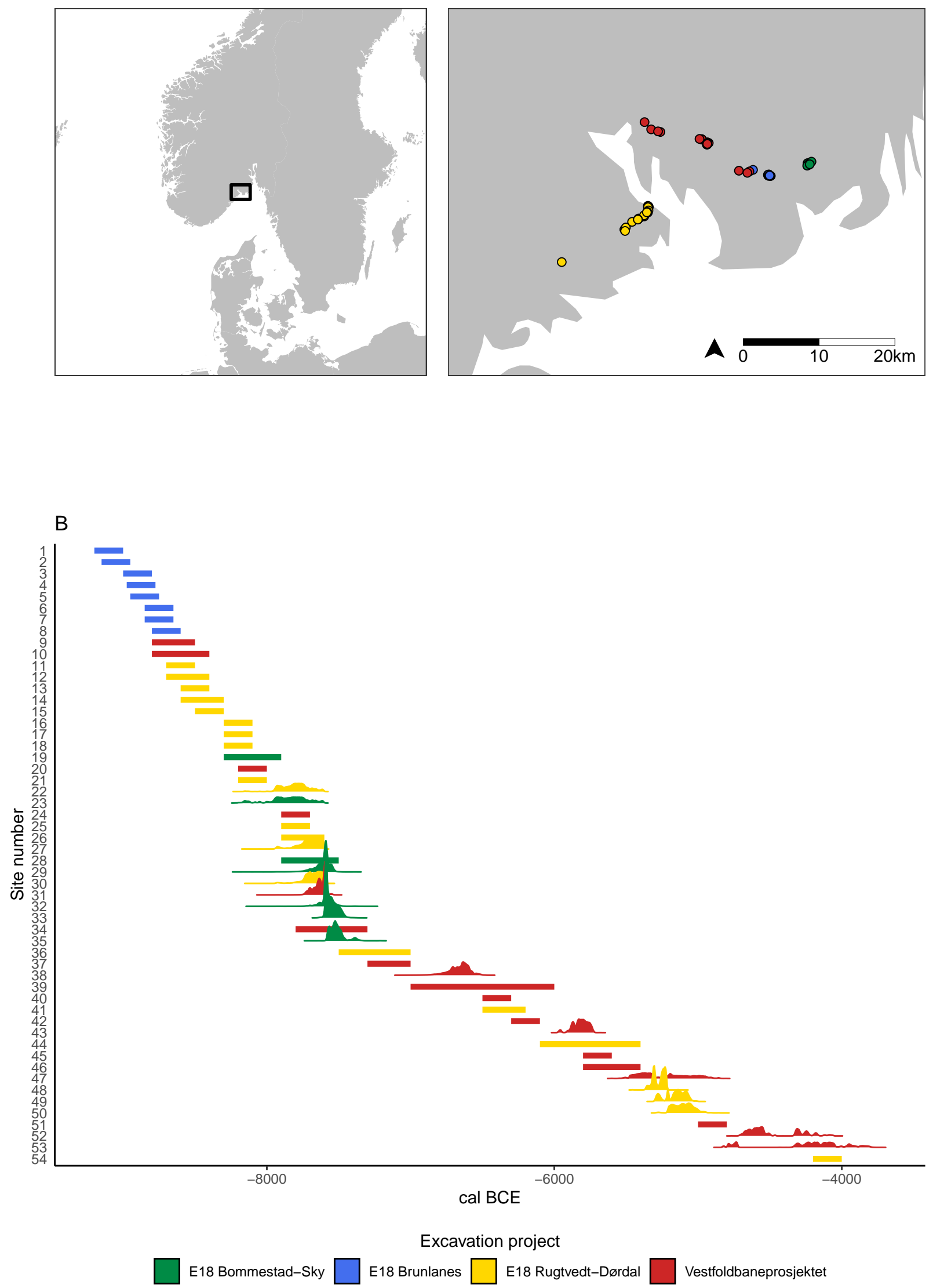

Figure 1: A) Spatial and B) temporal distribution of the sites chosen for analysis. Radiocarbon age determinations are given as the sum of the posterior density esimates. Solid lines indicate that the site has ${ }^{3}$ been dated with reference to relative sea-level change and typological indicators. These follow the original reports. Site numbers match those provided in Table 2. 
Table 1: Chronological framework. Glørstad's (2010) divison of phases reflects the more traditional framework, to which Reitan (2016) has recently suggested considerable changes.

\begin{tabular}{ll}
\hline Glørstad (2010) & \\
Early Mesolithic, Fosna Phase & $9500-8200$ BCE \\
Middle Mesolithic, Tørkop Phase & $8200-6300$ BCE \\
Late Mesolithic, Nøstvet Phase & $6300-4600$ BCE \\
Late Mesolithic, Kjeøy Phase & $4600-3800$ BCE \\
Reitan (2016) & \\
Flake Axe Phase & $9300-8200$ BCE \\
Microlith Phase & $8200-7000$ BCE \\
Pecked Adze Phase & $7000-5600$ BCE \\
Nøstvet Adze Phase & $5600-4500$ BCE \\
Transverse Arrowhead Phase & $4500-3900$ BCE \\
\hline
\end{tabular}

of the shoreline, following from isostatic rebound (e.g. Romundset et al. 2018; Sørensen 1979). The fairly rapid shoreline displacement means that the sites tend not to have retained their strategic or ecologically beneficial shore-bound location for long periods of time (cf. Perreault 2019:47). Consequently, the shore-bound settlement, combined with the rapid shoreline displacement has resulted in a relatively high degree of spatial separation of cumulative palimpsests, to follow the terminology of Bailey (2007), while the reconstruction of the trajectory of relative sea-level change allows for a relatively good control of when these accumulation events occurred. In other parts of the world, a higher degree of spatial distribution means that while the physical separation of material can help delineate discrete events, this typically comes at the cost of losing temporal resolution as any stratigraphic relationship between the events is lost (Bailey 2007).

The 54 coastal sites chosen for analysis here have a relatively limited geographical distribution (Figure 1A). The sites were excavated as part of four larger excavation projects that all took place within the last 15 years (Jaksland and Persson 2014; Melvold and Persson 2014; Reitan and Persson 2014; Solheim 2017a; Solheim and Damlien 2013). The sites included in the analysis consist of all Mesolithic sites excavated in conjunction with the projects that have assemblages holding more than 100 artefacts. The institution responsible for these excavations was the Museum of Cultural History in Oslo. This has led to a considerable overlap in the archaeological personnel involved, and comparable excavation practices across the excavations. Furthermore, with these projects, major efforts were made to standardise how lithic artefacts were to be classified at the museum (Koxvold and Fossum 2017; Melvold et al. 2014). As a result, this should reduce the amount of artificial patterning in the data incurred by discrepancies in the employed systems for categorisation (cf. Clark and Riel-Salvatore 2006; Dibble et al. 2017).

The lithic data analysed here is based on the classification of the site assemblages done for the original excavation reports, and consists of 48 debitage and tool types. These represent artefact categories that have been used consistently across the reports. Consequently, sub-categories that have only been used in the classification of some inventories have been omitted. This for example pertains to what blanks have been used for the production of formal tools, which has only been noted in some of the reports. Furthermore, the artefact data have been divided into flint and non-flint materials. Flint does not outcrop naturally in southern Norway, and is only available locally as nodules that have been transported and deposited by retreating and drifting ice (e.g. Berg-Hansen 1999). This means that the distribution and quality of flint has been impacted by a diverse set of climatic and geographical factors (Eigeland 2015:46). Thus, while flint is treated as a unified category here, the variability in quality could have been substantial. Furthermore, the various non-flint raw materials that have been lumped together have quite disparate properties, where fine-grained cryptocrystalline materials are often used as a substitute or supplement to flint, while other, coarser materials are usually associated with the production of axes and other macro tools. Given this differentiated use, these raw-material properties are expected to be reflected in the retained debitage and tool categories. An important benefit of combining all of the non-flint materials is that this reduces the dependency on whether or not these have been correctly and consistently categorised for the reports (cf. Frivoll 2017). Finally, 
while factors such as landscape changes through shoreline displacement can have led to variable raw-material availability at the analysed sites, for example by impacting accessibility by means of watercraft, the relatively constrained geographical distribution of the sites hopefully counteracts some environmentally given sources of variation.

Table 2: Analysed sites.

\begin{tabular}{|c|c|c|c|c|}
\hline no & Site name & Dating method & Reported start (BCE) & Reported end (BCE) \\
\hline 1 & Pauler 1 & Shoreline/typology & 9200 & 9000 \\
\hline 2 & Pauler 2 & Shoreline/typology & 9150 & 8950 \\
\hline 3 & Pauler 3 & Shoreline/typology & 9000 & 8800 \\
\hline 4 & Pauler 5 & Shoreline/typology & 8975 & 8775 \\
\hline 5 & Pauler 4 & Shoreline/typology & 8950 & 8750 \\
\hline 6 & Pauler 6 & Shoreline/typology & 8850 & 8650 \\
\hline 7 & Bakke & Shoreline/typology & 8850 & 8650 \\
\hline 8 & Pauler 7 & Shoreline/typology & 8800 & 8600 \\
\hline 9 & Nedre Hobekk 2 & Shoreline/typology & 8800 & 8500 \\
\hline 10 & Solum 1 & Shoreline/typology & 8800 & 8400 \\
\hline 11 & Tinderholt 3 & Shoreline/typology & 8700 & 8500 \\
\hline 12 & Tinderholt 2 & Shoreline/typology & 8700 & 8400 \\
\hline 13 & Dørdal & Shoreline/typology & 8600 & 8400 \\
\hline 14 & Tinderholt 1 & Shoreline/typology & 8600 & 8300 \\
\hline 15 & Skeid & Shoreline/typology & 8500 & 8300 \\
\hline 16 & Hydal 3 & Shoreline/typology & 8300 & 8100 \\
\hline 17 & Hydal 4 & Shoreline/typology & 8300 & 8100 \\
\hline 18 & Hydal 7 & Shoreline/typology & 8300 & 8100 \\
\hline 19 & Hovland 2 & Shoreline/typology & 8300 & 7900 \\
\hline 20 & Nedre Hobekk 3 & Shoreline/typology & 8200 & 8000 \\
\hline 21 & Hydal 8 & Shoreline/typology & 8200 & 8000 \\
\hline 22 & Hegna vest 1 & Radiocarbon & 8000 & 7800 \\
\hline 23 & Hovland 5 & Radiocarbon & 8000 & 7700 \\
\hline 24 & Sundsaasen 1 & Shoreline/typology & 7900 & 7700 \\
\hline 25 & Hegna øst 6 & Shoreline/typology & 7900 & 7700 \\
\hline 26 & Hegna vest 4 & Shoreline/typology & 7900 & 7600 \\
\hline 27 & Hegna vest 2 & Radiocarbon & 7900 & 7550 \\
\hline 28 & Nordby 2 & Shoreline/typology & 7900 & 7500 \\
\hline 29 & Hovland 4 & Radiocarbon & 7900 & 7500 \\
\hline 30 & Hegna vest 3 & Radiocarbon & 7800 & 7600 \\
\hline 31 & Prestemoen 1 & Radiocarbon & 7700 & 7600 \\
\hline 32 & Hovland 1 & Radiocarbon & 7700 & 7400 \\
\hline 33 & Hovland 3 & Radiocarbon & 7650 & 7450 \\
\hline 34 & Gunnarsrød 7 & Shoreline/typology & 7800 & 7300 \\
\hline 35 & Torstvet & Radiocarbon & 7500 & 7100 \\
\hline 36 & Hegna $\varnothing$ st 5 & Shoreline/typology & 7500 & 7000 \\
\hline 37 & Gunnarsrød 8 & Shoreline/typology & 7300 & 7000 \\
\hline 38 & Langangen Vestgård 1 & Radiocarbon & 6800 & 6600 \\
\hline 39 & Gunnarsrød 2 & Shoreline/typology & 7000 & 6000 \\
\hline 40 & Gunnarsrød 6b & Shoreline/typology & 6500 & 6300 \\
\hline 41 & Hegna $\varnothing$ st 7 & Shoreline/typology & 6500 & 6200 \\
\hline 42 & Gunnarsrød $6 \mathrm{a}$ & Shoreline/typology & 6300 & 6100 \\
\hline 43 & Gunnarsrød 4 & Radiocarbon & 6000 & 5800 \\
\hline 44 & Stokke/Polland 3 & Shoreline/typology & 6100 & 5400 \\
\hline 45 & Gunnarsrød 10 & Shoreline/typology & 5800 & 5600 \\
\hline 46 & Langangen Vestgård 2 & Shoreline/typology & 5800 & 5400 \\
\hline
\end{tabular}




\begin{tabular}{lllll}
47 & Vallermyrene 4 & Radiocarbon & 5500 & 5200 \\
48 & Hegna øst 2 & Radiocarbon & 5350 & 5200 \\
49 & Stokke/Polland 8 & Radiocarbon & 5300 & 5200 \\
50 & Stokke/Polland 5 & Radiocarbon & 5300 & 5000 \\
51 & Prestemoen 2 & Shoreline/typology & 5000 & 4800 \\
52 & Vallermyrene 1 & Radiocarbon & 4700 & 4100 \\
53 & Langangen Vestgård 3 & Radiocarbon & 4350 & 4000 \\
54 & Stokke/Polland 9 & Shoreline/typology & 4200 & 4000 \\
\hline
\end{tabular}

\section{The analysis of lithic assemblages}

Studies concerned with chronological changes in the composition of lithic assemblages in southern Norway have typically had a focus on morphological variation among artefacts (e.g. Ballin 1999; Bjerck 1986; Reitan 2016) or been concerned with technological processes associated with certain sub-categories of the site inventories, such as the production of blades or axes (e.g. Berg-Hansen 2017; Damlien 2016; Eymundsson et al. 2018; Solheim et al. 2020). Studies that have involved entire assemblages have either been concerned with general compositional traits such as relative frequency of various tool types and raw-materials (e.g. Breivik 2020; Breivik and Callanan 2016; Reitan 2016; Viken 2018), or involved extremely in-depth studies of technological organisation associated with a handful of assemblages (e.g. Eigeland 2015; Fuglestvedt 2007; Mansrud and Eymundsson 2016). These studies are, however, based on non-quantitative or descriptive uni- and bivariate methods, leaving the weighting of the many variables for the final interpretations unclear. To my knowledge, only a single study dealing with the composition of Mesolithic assemblages in southern Norway has involved the use of a multivariate quantitative framework, which was employed to structure the analysis of eight Middle Mesolithic assemblages (Solheim 2013; see Glørstad 2010:145-146 for a spatial application). In sum then, previous studies have typically either been limited to a small number of sites, to a subset of the inventories, to morphological characteristics, or to methods that are difficult to scale and consistently balance in the comparison of a larger number of artefact categories and assemblages.

The aim of the first of part of the analysis conducted here is to evaluate the degree to which the composition of the assemblages align with earlier studies that have employed more informal methods. This therefore assumes that the artefact categories employed in Norwegian Stone Age archaeology are, at least to a certain extent, behaviourally meaningful. However, the approach taken is also partially informed by the so-called Frison effect (Jelinek 1976), which pertains to the fact that lithics studied by archaeologists can have had long and complex use-lives in which they took on a multitude of different shapes before they were ultimately discarded. Several scholars have built on this to argue that morphological variation in retouched lithics from the Palaeolithic cannot be assumed to predominantly be the result of the intention of the original knapper to reach some desired end-product, but rather that what is commonly categorised as discrete types of artefacts by archaeologists can instead in large part be related to variable degrees of modification through use and rejuvenation (e.g. Barton 1991; Barton and Clark 2021; Dibble 1995). Consequently, artefact categories believed not to be internally consistent and categorically exclusive have therefore been collapsed for the analysis, as their contribution as discrete analytical units could potentially be misleading (Figure 2). An underlying assumption of the largely intuitively determined aggregation procedure is therefore effectively that the retained categories represent artefact categories that have fulfilled different purposes or are related to different technological processes. While aggregating artefact categories in this manner could subsume important variation, it does also reduce the possibility that any conclusions are not simply the result of employing erroneous units of analysis.

However, for the most part we lack even a most basic understanding of what any individual lithic object in an assemblage has been used for (Dibble et al. 2017). For example, a vast amount of artefacts defined as debitage are likely to have fulfilled the function of tools, and both debitage and formal tool types could have had various different purposes and had a multitude of shapes throughout their use-life. This has major implications that the above-outlined analysis does not take properly into account, rendering it difficult to align any identified pattern with specific behavioural dimensions. As a consequence, the second part of 


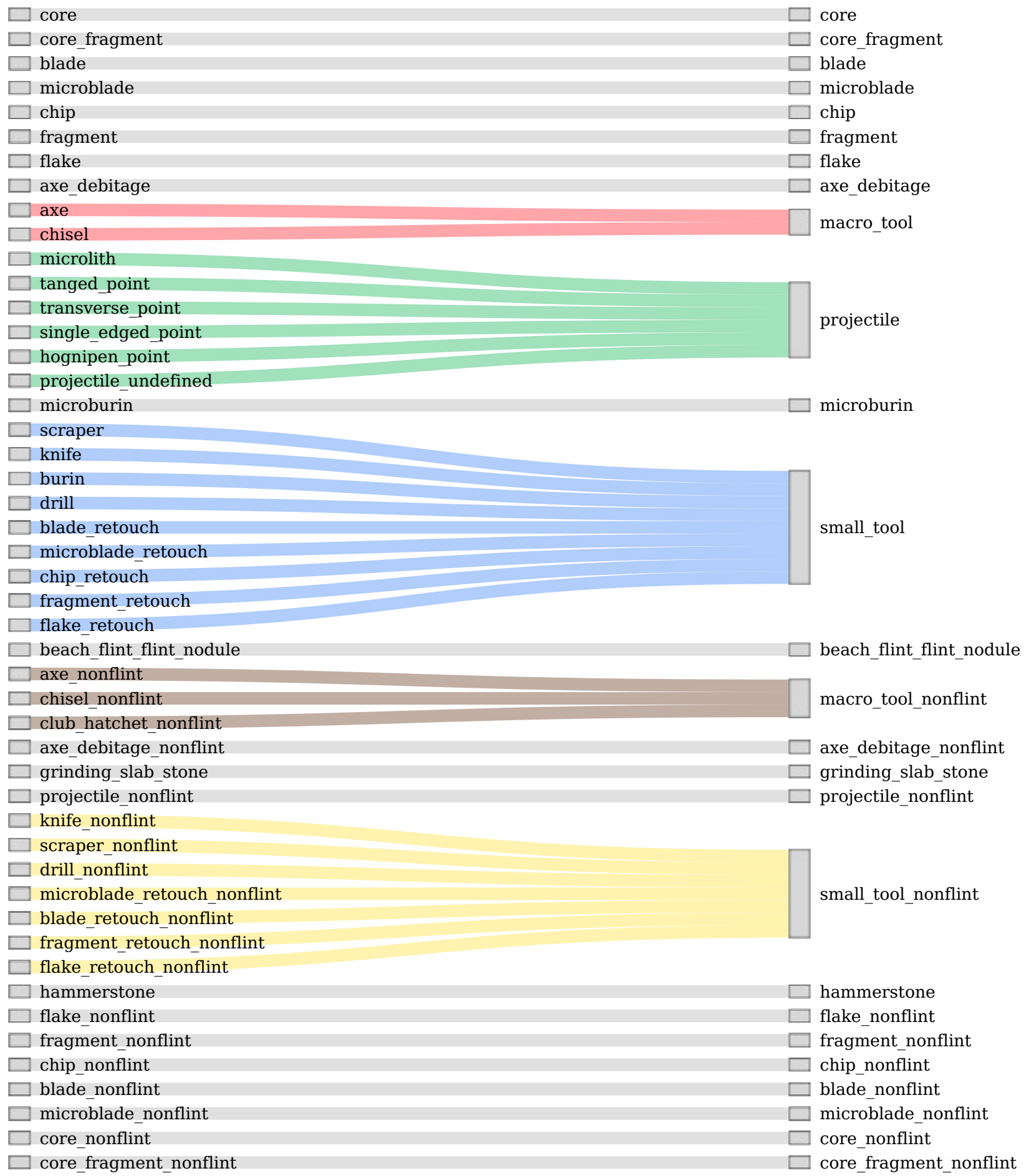

Figure 2: Aggregation of variables for the correspondence analysis. The column on the left shows the variables as originally compiled. The column on the right shows how these have been aggregated for the analysis. 
the analysis employs a suite of measures developed for the classification of lithic assemblages with these inferential limitations in mind (Barton et al. 2011; Clark and Barton 2017, and below). The logic behind these measures are founded on an understanding of technology as being organised along a continuum ranging between curated and expedient (Binford 1973, 1977, 1979). An expedient technological organisation pertains to the situational production of tools to meet immediate needs, with little investment of time and resources in modification and rejuvenation, resulting in high rates of tool replacement. Curated technological organisation, on the other hand, has been related to manufacture and maintenance of tools in anticipation of future use, the transport of these artefacts between places of use, and the modification and rejuvenation of artefacts for different and changing situations.

However, following not least from the ambiguous definition first put forward by Binford (1973), the theoretical definition of curation, its archaeological correlates, and behavioural implications have been widely discussed and disputed (e.g. Bamforth 1986; Nash 1996; Shott 1996; Surovell 2009:9-13). Still, that the distinction can offer a useful analytical point of departure if clearly and explicitly operationalised seems more or less agreed upon, and some dimensions of the concept are generally accepted. For example, although precisely how it is measured may vary, the empirical correspondent to a curated technological organisation is typically defined by high degrees of retouch, as this is commonly seen as a means of realising the potential utility of a tool —or extending its use-life - by the repeated rejuvenation and modification of edges (e.g. Bamforth 1986; Dibble 1995; Shott and Sillitoe 2005).

One concrete operationalisation of the terms has been forwarded by Barton (1998) and collegues (e.g. Barton et al. 1999, 2011, 2013; Barton and Riel-Salvatore 2014; Clark and Barton 2017; Riel-Salvatore and Barton 2004, 2007; Villaverde et al. 1998), who through a series of studies have shown that the relationship between volumetric density of lithics and relative frequency of retouched artefacts in lithic assemblages have a consistent negative relationship across a wide range of chronological and cultural context, ranging from Pleistocene and Holocene assemblages in Europe and Asia, to assemblages associated with both Neanderthals and modern humans (Barton et al. 2011; Riel-Salvatore et al. 2008). This relationship is taken to reflect degree of curation, and is in turn mainly to follow from the accumulated nature of land-use and mobility patterns associated with the assemblages (Barton and Riel-Salvatore 2014). Furthermore, the relationship between curated and expedient technological organisation has been related to the continuum defined by Binford (1980) between residentially mobile foragers and logistically mobile collectors (Clark and Barton 2017; Riel-Salvatore and Barton 2004; see also Bamforth 1986; Binford 1977). Residential mobility involves the relatively frequent movement of entire groups between resource patches throughout the year, while logistic mobility entails the use of central base-camps that are moved less often and from where smaller task-groups venture on targeted forays to retrieve specific resources. A higher degree of logistic as opposed to residential mobility thus also involves a wider range of site types and associated mobility patterns (Binford 1980).

Furthermore, in this model, higher degree of mobility would mean a higher dependency on the artefacts and the material people could bring with them, and dimensions such as weight, reliability, repairability, and the degree to which artefacts could be manipulated to fulfil a wide range of tasks are therefore assumed to have been factors of concern. From this it follows that the empirical expectation for short-term camps is a curated technological organisation with higher relative frequency of retouched artefacts, and a lower overall density of lithics (Clark and Barton 2017). More time spent in a single location, on the other hand, is assumed to lead to better control of raw-material availability and to allow for its accumulation. This should in turn lead to a more expedient technological organisation with reduced necessity for the conservation of lithics and extensive use of retouch. The empirical expectation for lower degree of mobility is therefore relatively high density of lithics, a low relative frequency of retouched artefacts, as well as a higher number of unexhausted cores and unretouched flakes and blades. These variables and underlying logic constitute what has been termed Whole Assemblage Behavioural Indicators (WABI, Clark and Barton 2017), and is the main framework adopted here.

As these measures are argued to predominantly be determined by land-use and mobility patterns, relative frequency of chips and relative frequency of non-flint material are also included in the analysis, as these measures have also been linked to mobility patterns (e.g. Bicho and Cascalheira 2020; Kitchel et al. 2021) and are of central importance to Norwegian Stone Age archaeology (e.g. Breivik et al. 2016; Reitan 2016) - the use of local non-flint material has been taken to indicate reduced mobility and increased familiarity with 
local surroundings (Glørstad 2010:181; Jaksland 2001:112).

\section{Methodology}

The exploratory approach taken here means that a wide range of combinations and transformations of variables has been explored to identify patterning in the data. While only parts of this process can sensibly be reported upon, all data and employed R programming scripts (R Core Team 2020) are freely available as a research compendium at https://osf.io/ehjfc/, following Marwick et al. (2018), allowing readers to explore and scrutinise the data and the final analytical choices made (Marwick 2017).

The 54 analysed sites have been dated by reference to relative sea-level change, typology and/or radiocarbon dates (Table 2). Date ranges for sites based on shoreline displacement and typology are taken from the original reports and follow the evaluation done by the original excavators. Where radiocarbon age determinations believed to be associated with the lithic material are available, these have been calibrated using the IntCal20 calibration curve (Reimer et al. 2020) and subjected to Bayesian modelling using OxCal v4.4.4 (Bronk Ramsey 2009) through the oxcAAR package (Hinz et al. 2021) for R. The only constraint imposed for the modelling of the dates was that the dates from each site are assumed to represent a related group of events through the application of the Boundary function (Bronk Ramsey 2021). The resulting posterior density estimates were then summed for each site.

The first part of the analysis involves employing the method of correspondence analysis (CA), using the lithic count data as classified for the original excavation reports (e.g. Baxter 1994; Shennan 1997). As this part of the analysis partially draws on the above-mentioned Frison effect, several artefact categories have been collapsed for the CA. A version of the CA using the original artefact categories, as well as some additional configurations and ways to aggregate the variables are also available in the supplementary material to the paper.

Following the WABI and other factors associated with mobility patterns, as presented above, the variables employed in the second part of the analysis are relative frequency of secondarily worked lithics (RFSL), defined as the proportion of the assemblages constituted by retouched or ground lithics; volumetric density of lithics (VDL), defined as the total number of artefacts divided by total excavated $\mathrm{m}^{3}$ as taken from the original reports; relative frequency of chips, defined as the proportion of artefacts with size $<1 \mathrm{~mm}$; relative frequency of cores, the proportion of all artefacts classified as cores in the original reports; relative frequency of blanks, here defined as the proportion of all artefacts classified as flakes, blades, micro-blades or fragments; and finally relative frequency of non-flint material. Following Bicho and Cascalheira (2020), the analysis is done using principal components analysis (PCA), leading to a shift in focus from the relative composition emphasised by the CA, to having more weight placed on patterning in the most abundant occurrences (Baxter 1994:71-77).

A note should also be made on the fact that a few variables that are sometimes invoked for the classification of sites in terms of associated mobility patterns are omitted here (e.g. Bergsvik 1995:116; Bicho and Cascalheira 2020; Breivik et al. 2016). For the assemblage data itself this especially pertains to diversity in tool-types (Canessa 2021), which has been omitted in light of the above-metioned Frison effect. Number of features on the sites has also been disregarded as taphonomic loss is likely to have led to a chronological bias in their preservation. Similarly, the number of activity areas, effectively number of artefact clusters, however defined, has also been disregarded. This follows most notably from the fact that the impact of post-depositional processes at Stone Age sites in Norway is arguably understudied (Jørgensen 2017). This pertains for example to bio-turbation in the form of three-throws, which can have a detrimental effect on the original distribution of artefacts, and which can be expected to have impacted several of the sites treated here (Darmark 2018; Jørgensen 2017). 


\section{Results}

The general impression from the CA is that a chronological dimension accounts for a substantial amount of patterning in the data (Figure 3). This is indicated by the general transition across the colour scale in the row plot (Figure 3B), as well as the horseshoe curve or Guttman effect evident in the column plot (Figure 3A, Baxter 1994:119-120; Lockyear 2000). The fact that the two first dimensions of the CA accounts for as much as $80.53 \%$ of the inertia or variance also means that the structure of the data is well-represented in the plots and that these therefore are likely reflect true patterning in the data.

The column plot reveals that the earliest sites are characterised by the flint artefact categories microburins, projectiles, as well as flint macro tools and associated debitage. These assemblages are also to a larger extent characterised by core fragments, both in flint and non-flint materials, rather than cores. The non-flint material on the earliest, or among the earliest sites, appears to be centred around the production of projectiles, as both projectiles and non-flint blades are important constituents of the assemblages at these sites. The first dimension, which is pulling some of the later sites towards the right of the plot, is mainly defined by macro tools and associated debitage in non-flint materials that are negatively correlated with more flint dominated assemblages. Site number 9, Nedre Hobekk 2, located in the upper right quadrant of the row plot represents a somewhat curious case in that it is an early assemblage characterised by axe production in metarhyolite (Eigeland 2014). However, the site had been quite heavily impacted by modern disturbances that could have impacted the lithic material and which could explain its position as an outlier in the plot. Finally, although the sample size is quite strained and the discussion of finer chronological points might not be warranted, the first dimension does appear to be of of less importance for the absolute latest sites, as indicated by their location to the left of the plot.

As most of the variation in the data is accounted for by the dominating non-flint material in later assemblages, this suppresses and makes it difficult to discern patterns in the flint data. A second CA was therefore performed, excluding the non-flint material (Figure 4). While not as substantial, there is clear temporal patterning in the flint data as well. This is most marked for the earliest sites which are pulled away from the main cluster, as projectiles, microburins, macro tools and debitage from their production characterises these sites. Slightly younger sites appear more impacted by core fragments and blades. The temporal transition in the main cluster is not as marked, but clearly present, and is driven by a larger proportion of blades, flakes and small tools in the earliest assemblages of the cluster, which is opposed to chips, fragments and partly micro-blades.

Moving on to the PCA of measures that have been linked to mobility, some of the variables with severely skewed distributions were initially transformed (Figure 5). Figure 6 displays the resulting PCA. There is a general temporal transition from the upper left to the bottom right of the plot. The second dimension is mainly defined by a negative correlation between the VDL and RFSL (Figure 7). Almost orthogonal to this is the strong negative correlation between relative frequency of chips and blanks. While there is a slight tendency for blanks to be more associated with younger sites, frequency of chips appears to be largely independent of time. However, this almost suspiciously strong negative correlation can perhaps have a practical explanation. Seeing as the frequency of non-flint material is positively correlated with blanks and negatively correlated with chips (Figure 5), one explanation to this pattern could be that smaller non-flint pieces are simply more difficult to identify and separate from naturally fragmented stone during excavation and classification. This could conceivably have led to an over-representation of blanks as compared to chips in assemblages with a high proportion of non-flint material. While this is not necessarily the entire explanation, this does make it difficult to place much analytical weight on this pattern. Relative frequency of cores is not especially impactful in the PCA, and appears to be independent of the temporal dimension as well. That is not to say that cores may not be indicative of or related to mobility patterns, but to get at this may require further analysis beyond their simple classification as cores (Kitchel et al. 2021).

Thus, while the relative frequency of blades and cores does not appear to meet the expectations of the WABI, it is difficult to say to what degree this is caused by idiosyncrasies in the Norwegian system for classification of lithics and properties of the lithic material itself. The relationship between VDL and RFSL does correspond to the model and follows a clear temporal trend that is also correlated with the increased use of local raw material. Thus, if the relationship between VDL and RFSL is accepted as a proxy for curation, and is related 


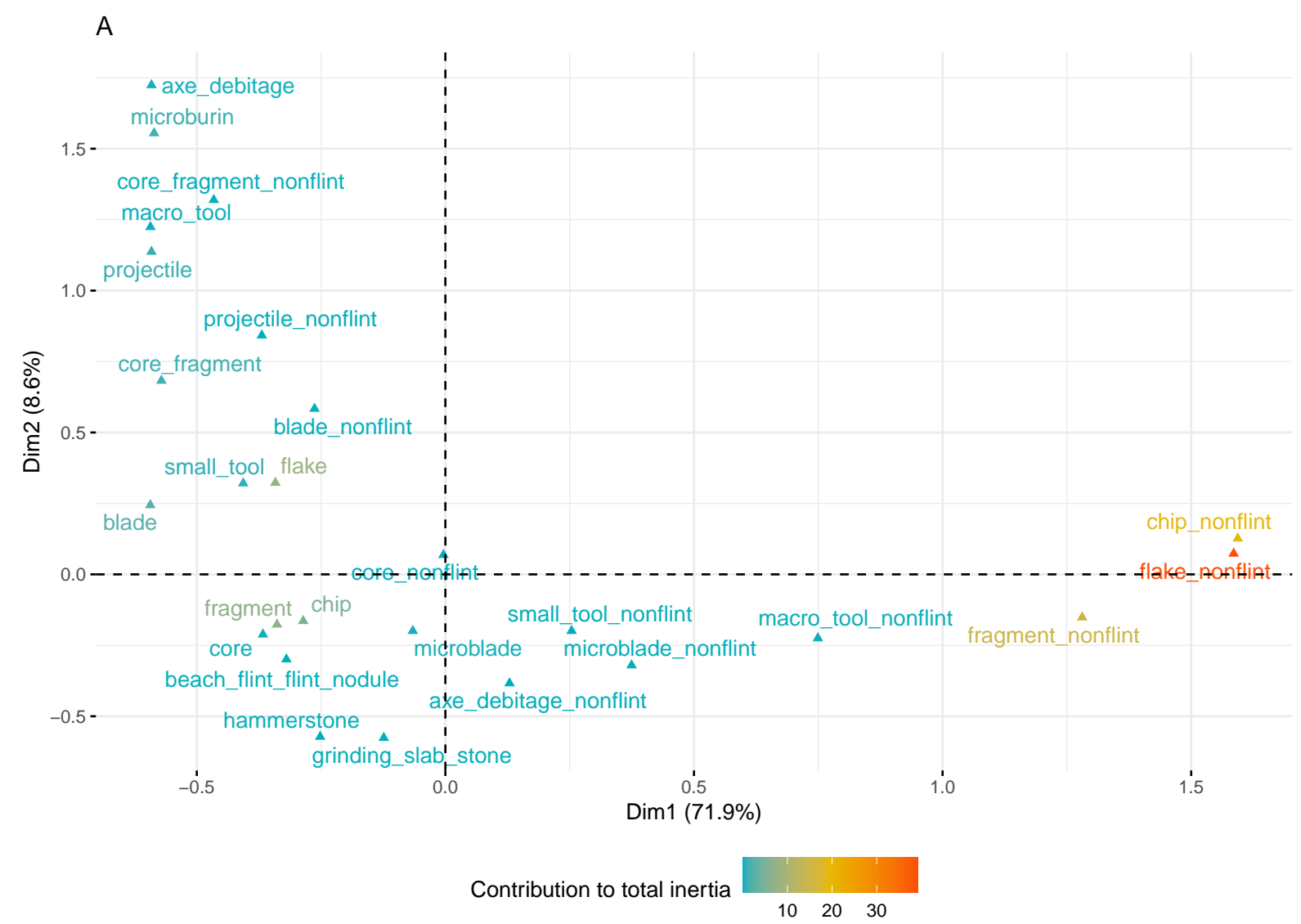

B

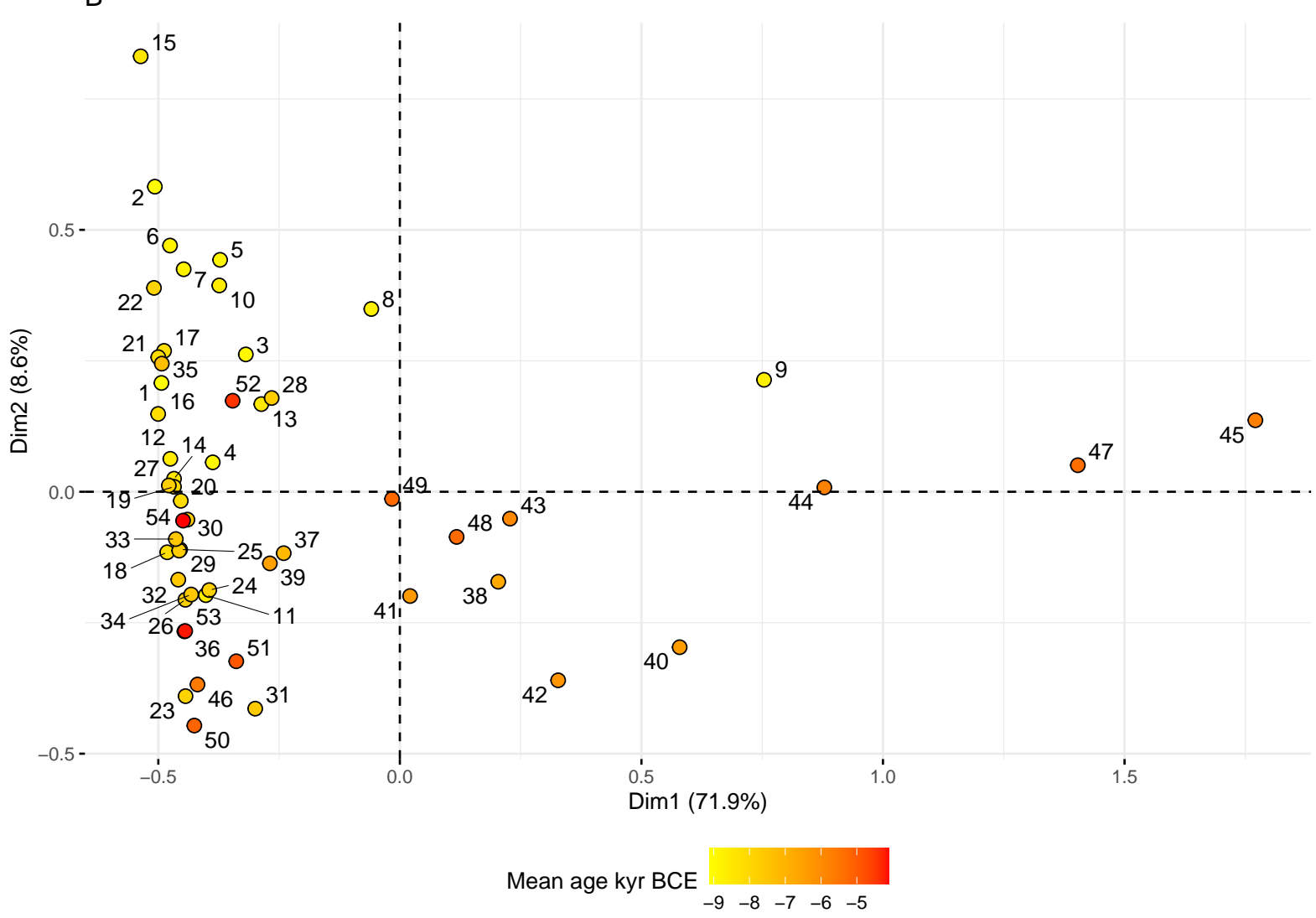

Figure 3: Correspondence analysis using the artefact count data. A) Column plot (variables), B) Row plot (sites). Points close together are more similar. By evaluating how the variables are distributed on the column ${ }^{11}$ plot it is possible to say how these define the two axes, in turn making it possible to relate the distribution of the sites in the row plot to the variables. As these are symmetrical plots, only general statements concerning the interrelation between the rows and the columns across the two plots can be made. 

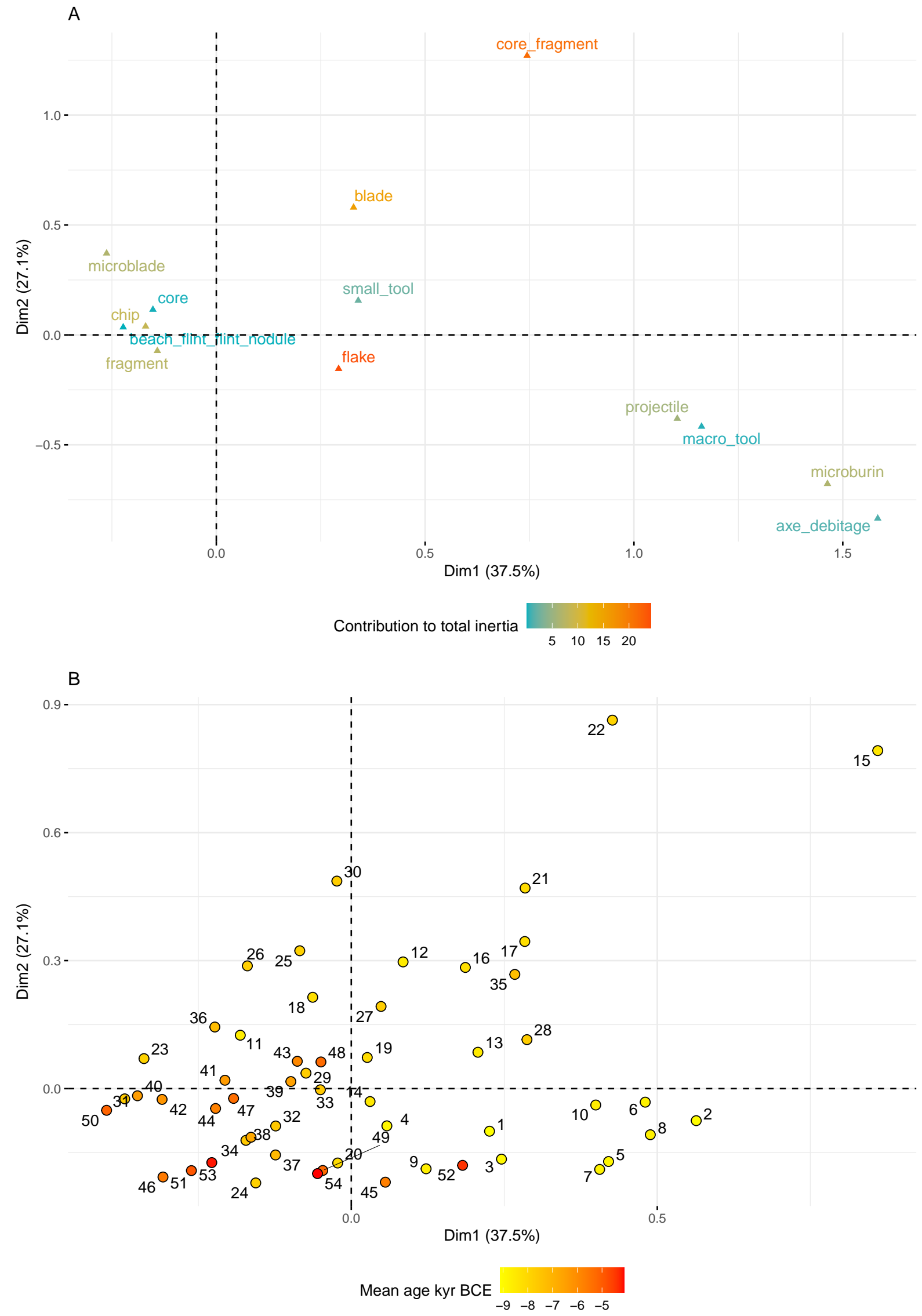

Figure 4: Correspondence analysis using the flint data. A) Column plot, B) Row plot. 
to land-use and mobility patterns, these findings would be in line with previous research into the Mesolithic of Norway, indicating that earlier sites are associated with higher degree of mobility than sites from later phases (e.g. Bergsvik 2001; Bjerck 2008; Glørstad 2010; Jaksland 2001). To explore this proposition further, these two variables are subjected to more detailed scrutiny below.

There is a strong negative correlation between the two variables $(r=-0.5)$ and a general tendency for younger sites to be associated with a higher VDL and a lower RFSL than older sites (Figure 8A). The linear correlation is stronger between the mean site age and RFSL $(r=-0.51)$, than between mean site age and VDL $(r=0.22)$. Variable non-flint availability and workability has also been suggested to potentially impact these dimensions (cf. Manninen and Knutsson 2014), but while the negative correlation is slightly less marked when only the flint data is considered $(r=-0.4)$, the general pattern is the same (Figure $8 \mathrm{~B}$ ). The relationship between mean site age and relative frequency of secondarily worked flint is even stronger $(r=-0.57)$, but as indicated by the more spread out distribution along the $\mathrm{x}$-axis, the volumetric density of flint is not temporally contingent $(r=0.1)$. As was also indicated by the CA, this follows from the fact that non-flint materials make up a higher share of the assemblages for some of the later Mesolithic sites, and is a point returned to below where the temporal dimension of the relationship between VDL and RFSL is explored further.

To get more directly at this temporal trend, a curation index based on VDL and RFSL was devised by first performing a min-max normalisation of the two variables, scaling them to take on values between 0 and 1 . The value for artefact density was then made negative to reflect its relationship with degree of curation. The mean was then found for each site on these two normalised values. To account for the temporal uncertainty associated with the dating of the sites, a simulation-based approach was also adopted (e.g. Crema 2012; Orton et al. 2017). A LOESS curve was fit to the curation index and site age for each simulation run, where the age of each site was drawn as a single year from their respective date ranges as provided in Figure 1. For sites with radiocarbon age determinations the dates were drawn from the summed posterior density estimates, while ages for sites dated with reference to relative sea-level change and typology were drawn uniformly from the associated date range (Figure 9). This simulation was repeated 1000 times. Disregarding the edge-effects at either end of the plot, the general tendency is a relatively high degree of curation among the earlier sites, followed by a marked drop around $8000 \mathrm{BCE}$. This has stabilised by around $7000 \mathrm{BCE}$ and remains stable for the rest of the Mesolithic. The variation in degree of curation is also markedly higher after 8000 BCE. Figure 9B displays the result of running the same procedure on the flint data. The general pattern follows the same trajectory, but the result for some individual sites is noticeably different.

\section{Discussion}

The results of the CA appear to align well with previous research (e.g. Solheim 2017b, with references). In the flint material the earliest sites are separated from the rest primarily based on the presence of macro tools, microburins, projectiles, and, for slightly younger sites, core fragments and blades (cf. Bjerck 2017; Breivik et al. 2018; Damlien and Solheim 2018; Fuglestvedt 2009; Jaksland and Fossum 2014). The importance of the latter two can be associated with the blade technology that is introduced with the Middle Mesolithic, characterised by blade production from conical and sub-conical cores with faceted platforms that involves the removal of core tablets and rejuvenation flakes (Damlien 2016). When it comes to the non-flint material, projectiles are to a larger extent a property of the earlier sites than later ones. The use of metarhyolite for the production of axes is present at some earlier sites in addition to the previously mentioned Nedre Hobekk 2 , and the production of non-flint hatchets and core axes is introduced in the Microlith Phase (Eymundsson et al. 2018; Jaksland and Fossum 2014; Reitan 2016). However, in agreement with the literature, this is evidently not as prominent a part of these assemblages.

The flint material of the later sites is to a larger extent characterised by micro-blades, which corresponds to the transition to micro-blade production from handle cores (e.g. Solheim et al. 2020). A more fragmented flint material, as indicated by the relative importance of flint chips and fragments, is also a previously noted property of some later Mesolithic, as well as early Neolithic sites (e.g. Fossum 2017; Stokke and Reitan 2018). The most defining material for the later sites, however, is non-flint macro tools and associated debitage, which is dominating some of these assemblages. It was noted above that this material does not seem to impact 


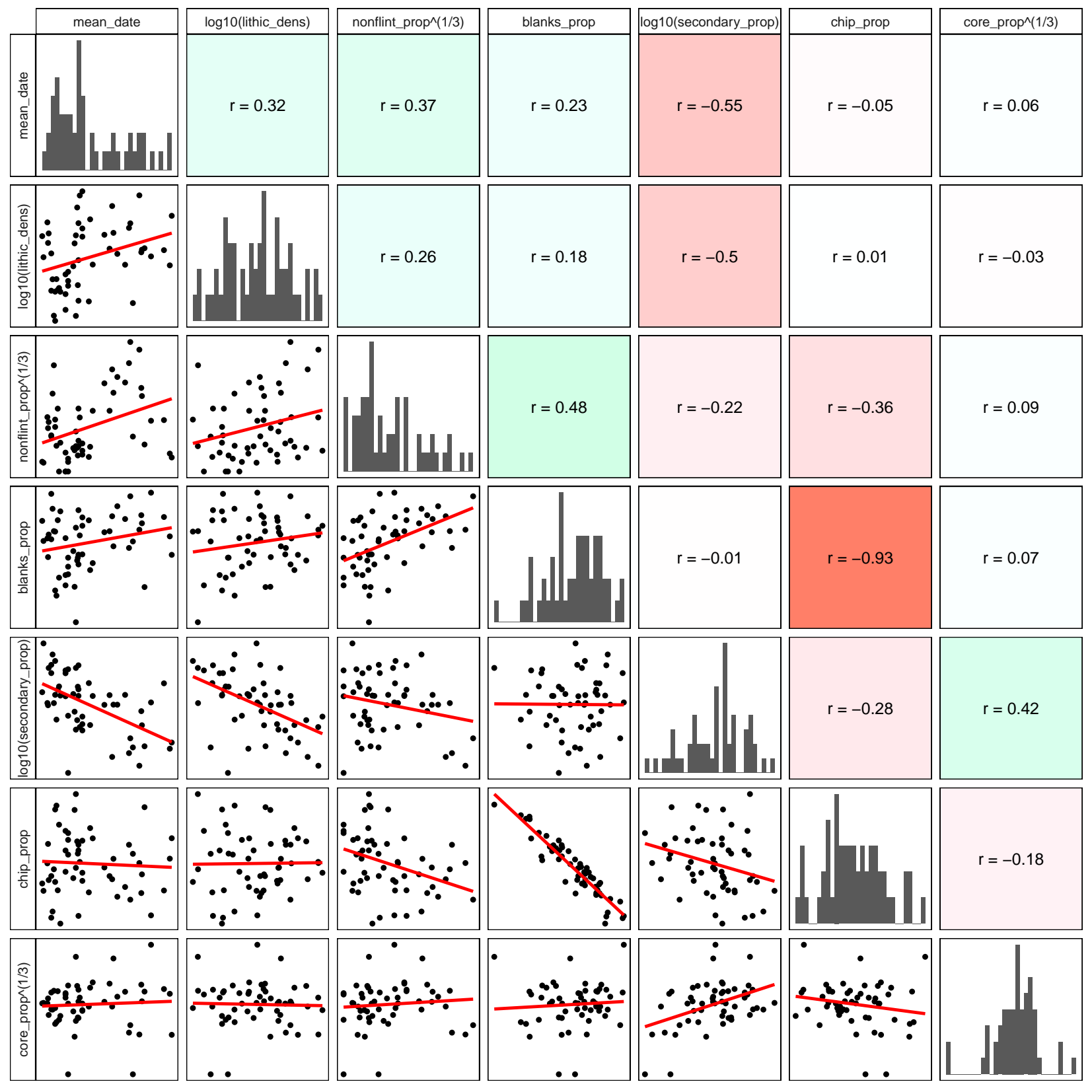

Figure 5: Correlation matrix showing transformation of skewed variables for the PCA. The mean age of the sites has also been included to visualise overall temporal trends. Cells below the diagonal display the bivariate distributions with a fitted OLS-regression. The cells above the diagonal display and are coloured by the corresponding Pearson's correlation coefficient. 


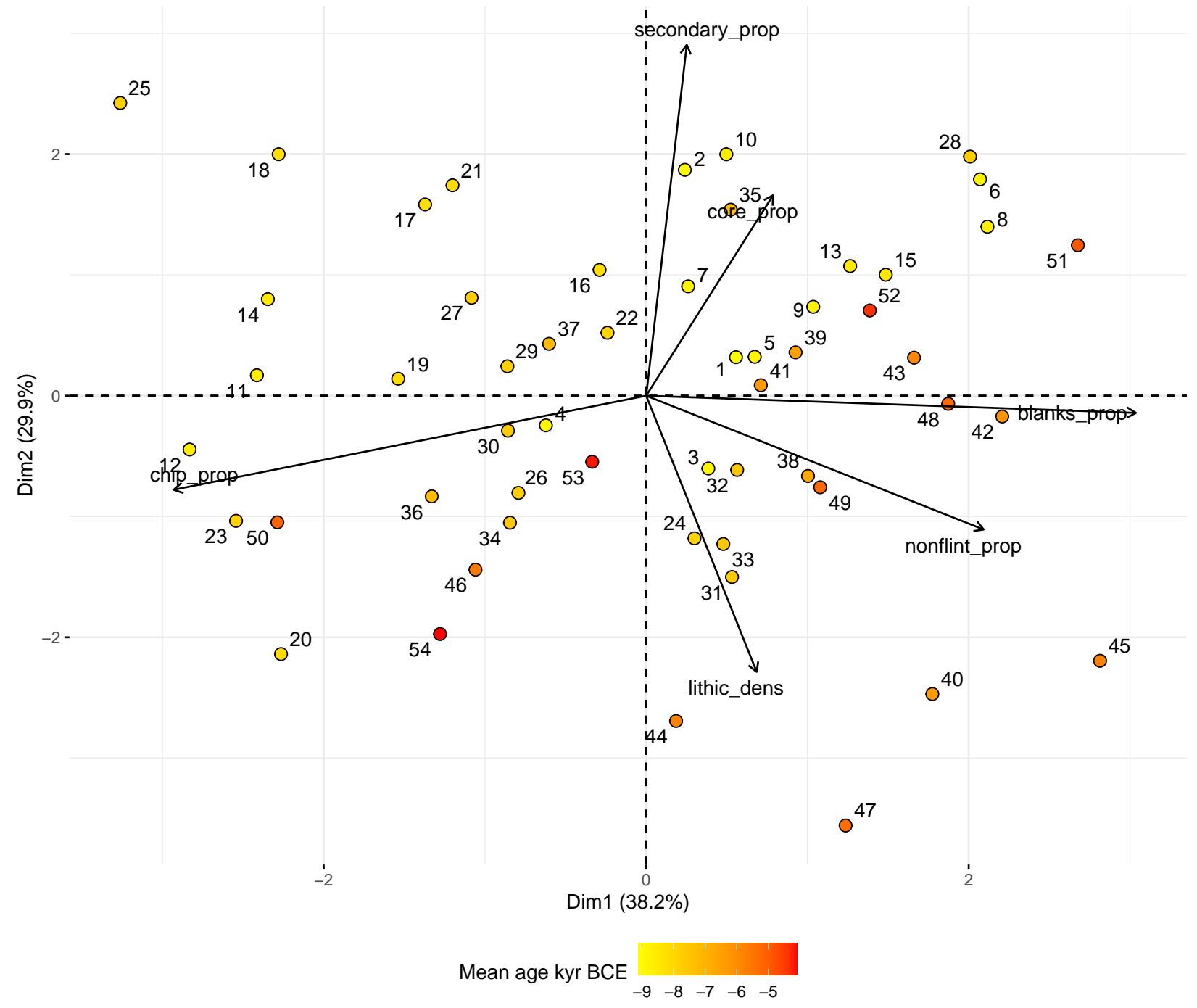

Figure 6: PCA biplot resulting from analysing variables that have been related to mobility patterns. Note that details on the transformation of the variables has been left out of the plot for clarity, but follow those given in Figure 5 . 
Contribution of variables to Component 1

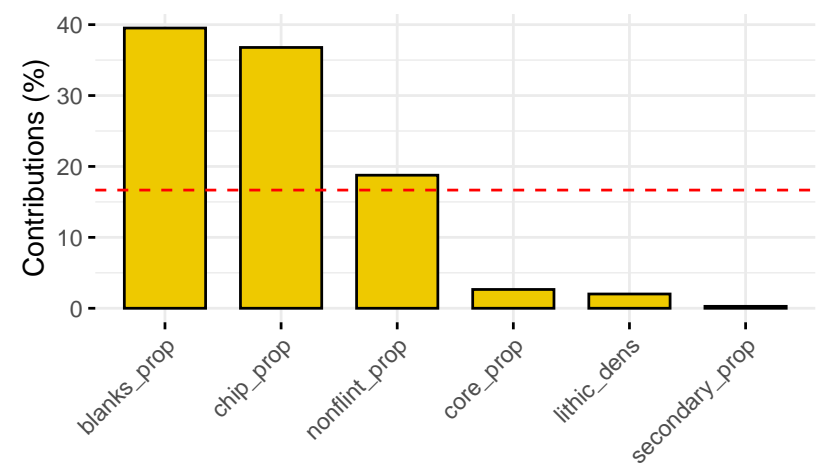

Contribution of variables to Component 2

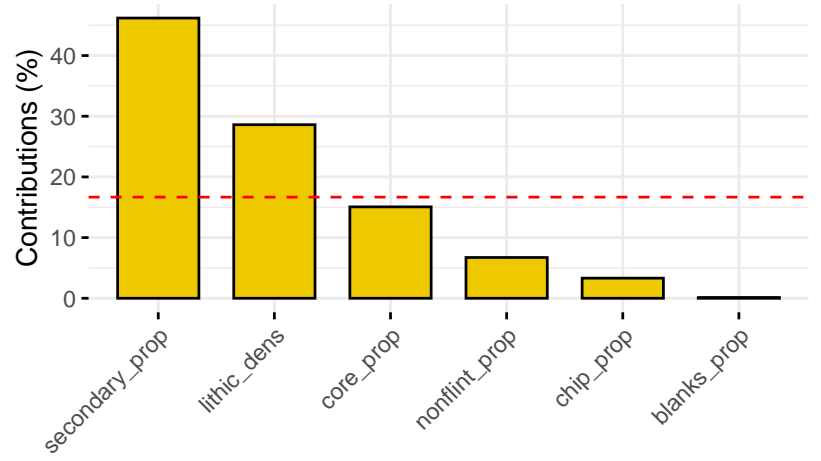

Figure 7: Contribution of variables to the first two components of the PCA. The dotted red line indicates the expected contribution from each variable given a uniform distribution of impact.
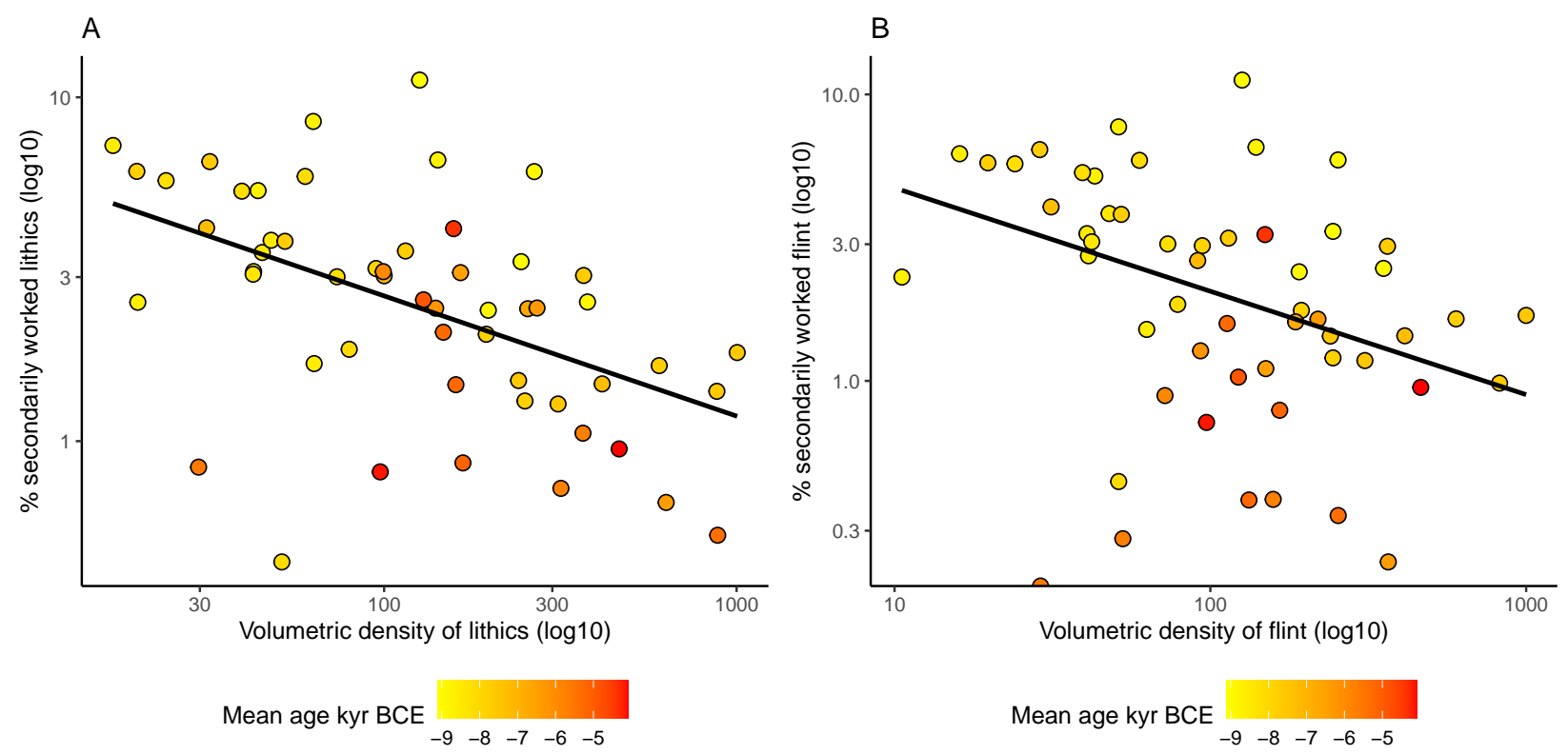

Figure 8: Relative frequency of secondarily worked lithics plotted against the volumetric density of artefacts for A) All lithics $(r=-0.5)$, B) Flint $(r=-0.4)$. The logarithm is taken to base 10 on all axes. 

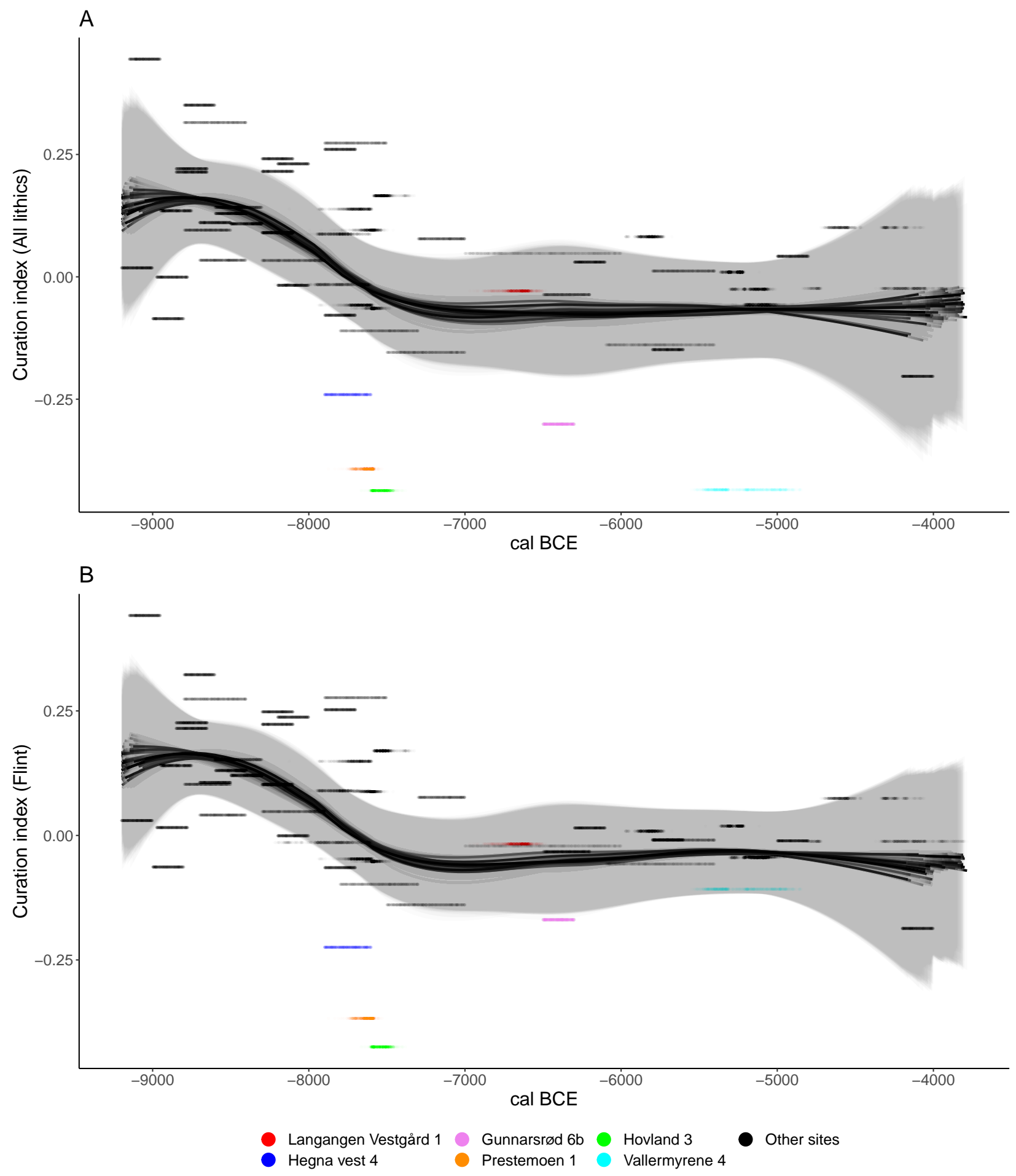

Figure 9: Temporal variation in the curation index for A) All lithics, and B) Flint. The temporal uncertainty is handled by means of a simulation approach where the site ages are drawn from their respective age determination probability density functions given in Figure 1B. A LOESS curve has been fit to the distribution for each of the 1000 simulation runs. Each simulation run is plotted with some transparency. Sites mentioned in the text are given colour. 
the latest sites, which would indicate that specialised axe production sites disappear towards the end of the Mesolithic, a notion that would be in line with previous suggestions (e.g. Glørstad 2011; Reitan 2016).

One implication of the fact that the employed artefact categories are so clearly capturing a temporal component could be that the aggregation of artefact categories might have been overly conservative. However, it is also evidently clear, in the words of Kruskal (1971:22), that 'time is not the only dimension.' The results of the CA do most certainly correspond to more pervasive cultural change than a purely typo-chronological development of artefact morphology, which is also made evident by some significant deviances from the overall pattern. Unpicking and aligning these patterns with any specific behavioural and technological dimensions using the coarse CA results is, however, another task entirely. This follows most clearly from the fact that for the most part we do not know what individual lithic objects in the assemblages have been used for, leaving the behavioural and social significance of the employed units of analysis unclear. The results of the CA can, however, be used in conjunction with the part of the analysis that has attempted to get at more specific behavioural dimensions to nuance or explain discrepancies in this data.

The curation index has relatively high values until some time before $8000 \mathrm{BCE}$, before it drops and stabilises around $7000 \mathrm{BCE}$. This pattern is evident in both the flint data and when all lithics are treated in aggregate. Furthermore, the increased variation in degree of curation after around $8000 \mathrm{BCE}$ could indicate that these sites were associated with a more varied mobility pattern. The five sites that have values on the curation index below c. -0.25 could in this perspective have predominantly functioned as base-camps within a logistic settlement pattern. That these assemblages reflect stays of a longer duration was suggested for all five sites in the original reports (Carrasco et al. 2014; Eigeland and Fossum 2017; Persson 2014; Solheim and Olsen 2013), with the exception of for Vallermyrene 4, which was argued to be a specialised axe production site, not necessarily associated with lower degrees of mobility (Eigeland and Fossum 2014). This highlights a possible issue pertaining to raw-material variability, as the coarse non-flint material used for the production of axes generally results in a relatively large amount of waste per produced tool, possibly skewing the curation index when compared to assemblages dominated by flint. Referring back to the CA, the difference is most marked for the sites in the later part of the Mesolithic where non-flint material become more dominating parts of the assemblages. As can be seen in Figure 9B, the degree of curation is markedly higher for both Gunnarsrød 6b and Vallermyrene 4 when the non-flint material is excluded, although they remain more expedient than that of contemporary assemblages. Thus, the degree of expediency for assemblages dominated by non-flint might be somewhat exaggerated when the non-flint material is included, while its exclusion would likely lead to its underestimation. One possible approach could be to weigh the curation index by the proportion of non-flint material in the assemblages. This is not explored further here, however, as the overall tendencies appear robust to this effect.

Another case also worth commenting on is Langangen Vestgård 1, which, on the grounds of an overall large number of artefacts and the possible presence of a dwelling structure was argued to reflect a more permanent site location in the original report (Melvold and Eigeland 2014). However, the relatively high value on the curation index could mean that the site reflects the aggregation of stays which predominantly have been of a comparable duration to those on contemporary sites, while the possible dwelling structure, if taken as an indication of longer stays, could in this perspective represent a remnant from one or a few visits of longer duration that constitute a smaller fraction of the use-life of the site as a whole (cf. Barton and Riel-Salvatore 2014).

While there are certainly nuances in the material that might lead one to question the applicability of the VDL and RFSL measures for any individual site, the overall pattern for curation does appear robust. The curation index is relatively high and uniform until some time before $8000 \mathrm{BCE}$. This corresponds well with the view that the Early Mesolithic is characterised by a high and uniform degree of mobility. This is followed by a marked increase in expedience, which has stabilised by around $7000 \mathrm{BCE}$. Again, this corresponds well with the employed chronological framework. Referring back to the demographic changes that are to take place around this transition, the Microlith phase could thus represent a period where migrating people and new living practices were propagating through societies in south-eastern Norway - a process that in light of the curation data would have concluded around 7000 BCE.

The curation index then remains stable for the rest of the Mesolithic. This suggests that the transition to 
mobility patterns traditionally ascribed to the Nøstvet Phase can indeed be traced back to the Microlith Phase (cf. Solheim and Persson 2016). The continued stability of the curation index could also indicate that the demographic changes suggested to take place in the Transverse Arrowhead Phase are not related to major shifts in land-use and mobility patterns. However, it is worth highlighting the strained sample size for the later parts of the Mesolithic, which could mean that the effect is simply missed.

As it stands, the main hypotheses resulting from the present analysis would be that settlement patterns in the earliest parts of the Mesolithic were characterised by relatively high and uniform degrees of mobility, which then drop before levelling off at around 7000 BCE. These then remain stable throughout the rest of the period, despite variation pertaining to other aspects of the lithic inventories, as evidenced by the CA. The fall in curation levels and parallel increase in variation would seem to correlate well with a transition from a predominantly residential to logistical settlement system (Binford 1980). This indicates, in turn, that the measures represent an empirical link between technological organisation and economic behaviour and mobility patterns (Riel-Salvatore and Barton 2004).

\section{Conclusion}

The results of the CA align well with results of previous research in south-eastern Norway, indicating that meaningful chronological patterning is associated with the employed artefact categories. These tendencies are already well-established when it comes to the formal tool types and some debitage categories, but have been given less focus in light of entire assemblages. Precisely what behavioural implication the development in the occurrences of the tool and debitage categories have are less clear, but appears to follow a different and more complex development over time than that of curation, as operationalised here.

The temporal trends associated with the curation index corresponds surprisingly well with trajectories of cultural development previously suggested in the literature, and does therefore, in my view, suggest that shifts in land-use and mobility patterns are the main drivers behind this empirical pattern - in line with the framework of Barton et al. (2011). Another perspective would be that this is not surprising at all (cf. Kuhn and Clark 2015:14), and that the previously demonstrated relevance of these measures across a wide range of contexts points to their pervasive relevance for the organisation of lithic technology, and, therefore, that there should be little reason to think Mesolithic south-eastern Norway should be any different. However, the conclusion that these these measures apply to and appear to capture the dimensions of interest in a relatively controlled empirical setting, reached by means of an exploratory analysis can only constitute a first analytical step. As Elster (2015:12) has pointed out, the human mind seems to have a propensity to settle for an explanation that can be true, as soon as this has been reached. This, however, can only constitute the absolute minimum of what is required of a proposed explanation. Subsequent steps should be to probe and challenge this explanatory framework, also in light of alternative hypotheses (e.g. Clark 2009:29-30; Perreault 2019:1-22). The empirical relationship does nonetheless hold great potential for large scale comparative studies in Mesolithic Scandinavia and beyond. Furthermore, the curation index was here simply narratively associated with the most immediate chronological trends emphasised in the literature concerned with the Mesolithic of south-eastern Norway. The explicit quantification does, however, offer the possibility to conduct formal comparisons with a wide range of environmental, demographic and cultural dimensions across multiple scales of analysis. 


\section{Declaration of interest}

The author has no conflicts of interest to declare.

\section{References}

Andrefsky, William

2009 The analysis of stone tool procurement, production, and maintenance. Journal of Archaeological Research 17(1):65-103. DOI:10.1007/s10814-008-9026-2.

Åstveit, Leif Inge

2014 Noen synspunkt på den tidligmesolittiske bosetningen i Sør-Norge. Primitive tider 16:87-104. DOI:10.5617/pt.7233.

2018 The Early Mesolithic of Western Norway. In Early Economy and Settlement in Northern Europe. Pioneering, Resource Use, Coping with Change, edited by Hans Peter Blankholm, pp. 231-274. Equinox, Sheffield.

Bailey, Geoff

2007 Time perspectives, palimpsests and the archaeology of time. Journal of Anthropological Archaeology 26(2):198-223. DOI:10.1016/j.jaa.2006.08.002.

Ballin, Torben Bjarke

1999 The Middle Mesolithic in Southern Norway. In The Mesolithic of Central Scandinavia, edited by Joel Boaz, pp. 203-216. University of Oslo, Oslo.

Bamforth, Douglas B.

1986 Technological Efficiency and Tool Curation. American Antiquity 51(1):38-50. DOI:10.2307/280392.

Barton, C. Michael

1991 Retouched Tools, Fact or Fiction? Paradigms for Interpreting Paleolithic Chipped Stone. In Perspectives on the Past. Theoretical Biases in Mediterranean Hunter-Gatherer Research, edited by Geoffrey A. Clark, pp. 143-163. University of Pennsylvania Press, Philadelphia.

1998 Looking back from the world's end: paleolithic settlement and mobility at Gibraltar. In Las Culturas del Pleistoceno Superior en Andalucia, edited by José Luis Sanchidrián and María Dolores Simón Vallejo, pp. 13-22. Patronato de la Cueva de Nerja, Nerja.

Barton, C. Michael, Joan Bernabeu, J. Emili Aura, and Oreto García

1999 Land-Use Dynamics and Socioeconomic Change: An Example from the Polop Alto Valley. American Antiquity 64(4):609-634. DOI:10.2307/2694208.

Barton, C. Michael, and Geoffrey A. Clark

2021 From Artifacts to Cultures: Technology, Society, and Knowledge in the Upper Paleolithic. Journal of Paleolithic Archaeology 4(2):16. DOI:10.1007/s41982-021-00091-8.

Barton, C. Michael, and Julien Riel-Salvatore

2014 The Formation of Lithic Assemblages. Journal of Archaeological Science 46:334-352. DOI:10.1016/j.jas.2014.03.031.

Barton, C. Michael, Julien Riel-Salvatore, John M. Anderies, and Gabriel Popescu

2011 Modeling Human Ecodynamics and Biocultural Interactions in the Late Pleistocene of Western Eurasia. Human Ecology 39(6):705-725. DOI:10.1007/s10745-011-9433-8.

Barton, C. Michael, Valentin Villaverde, João Zilhão, J. Emili Aura, Oreto Garcia, and Ernestina Badal

2013 In glacial environments beyond glacial terrains: Human eco-dynamics in late Pleistocene Mediterranean Iberia. Quaternary International 318:53-68. DOI:10.1016/j.quaint.2013.05.007.

Baxter, Michael J.

1994 Exploratory Multivariate Analysis in Archaeology. Percheron Press, New York. 
Berg-Hansen, Inger Marie

1999 The Availability of Flint at Lista and Jæren, Southwestern Norway. In The Mesolithic of Central Scandinavia, edited by Joel Boaz, pp. 255-266. University of Oslo, Oslo.

2017 Den sosiale teknologien. Teknologi og tradisjon i Nord-Europa ved slutten av istida, 10900 - 8500 f.Kr. Unpublished PhD thesis, Oslo.

Bergsvik, Knut Andreas

1995 Bosetningsmønstre på kysten av Nordhordland i steinalder. En geografisk analyse. In Arkeologiske skrifter 8. Steinalderkonferansen i Bergen 1993, edited by Knut Andreas Bergsvik, Signe Nygaard, and Arne Johan Nærøy, pp. 111-130. University of Bergen, Bergen.

2001 Sedentary and Mobile Hunterfishers in Stone Age Western Norway. Arctic Anthropology 38(1):2-26.

Bevan, Andrew

2015 The data deluge. Antiquity 89(348):1473-1484. DOI:10.15184/aqy.2015.102.

Bicho, Nuno, and João Cascalheira

2020 Use of lithic assemblages for the definition of short-term occupations in hunter-gatherer prehistory. In Short-term occupations in Paleolithic archaeology: Definition and interpretation, edited by João Cascalheira and Andrea Picin, pp. 19-38. Springer, Cham.

Binford, Lewis R.

1973 Interassemblage variability - the Mousterian and the "functional" argument. In The explanation of culture change: Models in prehistory, edited by Colin Renfrew, pp. 227-254. Duckworth, London.

1977 Forty-seven trips: A case study in the character of archaeological fomation processes. In Stone Tools as Cultural Markers: Change, Evolution and Complexity, edited by R. V. S. Wright, pp. 24-36. Australian Institute of Aboriginal Studies, Canberra.

1979 Organization and Formation Processes: Looking at Curated Technologies. Journal of Anthropological Research 35(3):255-273. DOI:10.1086/jar.35.3.3629902.

1980 Willow Smoke and Dogs' Tails: Hunter-Gatherer Settlement Systems and Archaeological Site Formation. American Antiquity 45(1):4-20. DOI:10.2307/279653.

Bjerck, Hein Bjartmann

1986 The Fosna-Nøstvet Problem. A Consideration of Archaeological Units and Chronozones in the South Norwegian Mesolithic Period. Norwegian Archaeological Review 19(2):103-121. DOI:10.1080/00293652.1987.9965440.

2008 Norwegian Mesolithic Trends: A Review. In Mesolithic Europe, edited by Geoff Bailey and Penny Spikins, pp. 60-106. Cambridge University Press, Cambridge.

2017 Settlements and Seafaring: Reflections on the Integration of Boats and Settlements Among Marine Foragers in Early Mesolithic Norway and the Yámana of Tierra del Fuego. The Journal of Island and Coastal Archaeology 12(2):276-299. DOI:10.1080/15564894.2016.1190425.

Breivik, Heidi Mjelva

2020 Diachronic trends among Early Mesolithic sites types? A study from the coast of central Norway. In Coastal Landscapes of the Mesolithic: Human Engagement with the Coast from the Atlantic to the Baltic Sea, edited by Almut Schülke, pp. 121-146. Routledge, London \& New York.

Breivik, Heidi Mjelva, Hein Bjartmann Bjerck, Francisco J Zangrando, and Ernesto L Piana

2016 On the Applicability of Environmental and Ethnographic Reference Frames: An Example from the High-Latitude Seascapes of Norway and Tierra del Fuego. In Marine Ventures: Archaeological Perspectives on Human-Sea Relations, edited by Hein Bjartmann Bjerck, Heidi Mjelva Breivik, Silhe E Fretheim, Ernesto L Piana, Skar Birgitte, Angélica M Tivoli, and Francisco J Zangrando, pp. 75-94. Equinox, Sheffield.

Breivik, Heidi Mjelva, and Martin Callanan

2016 Hunting High and Low: Postglacial Colonization Strategies in Central Norway between 9500 and 8000 cal BC. European Journal of Archaeology 19(4):571-595. DOI:10.1080/14619571.2016.1147315. 
Breivik, Heidi Mjelva, Guro Fossum, and Steinar Solheim

2018 Exploring human responses to climatic fluctuations and environmental diversity: Two stories from Mesolithic Norway. Quaternary International 465:258-275. DOI:10.1016/j.quaint.2016.12.019.

Bronk Ramsey, Christopher

2009 Bayesian Analysis of Radiocarbon Dates. Radiocarbon 51(1):337-360. DOI:10.1017/S0033822200033865.

2021 OxCal 4.4 manual. https://c14.arch.ox.ac.uk/oxcalhelp/hlp_contents.html.

Canessa, Timothy

2021 Mobility and settlement strategies in southern Iberia during the Last Glacial Maximum: Evaluating the region's refugium status. Journal of Archaeological Science: Reports 37:102966. DOI:10.1016/j.jasrep.2021.102966.

Carrasco, Lotte, Inger Margrete Eggen, Lotte Eigeland, Guro Fossum, Stine Melvold, Per Persson, and Gaute Reitan

2014 Gunnarsrød 6. Et boplassområde fra overgangen mellommesolitikum-seinmesolitikum. In Vestfoldbaneprosjektet. Arkeologiske undersøkelser $i$ forbindelse med ny jernbane mellom Larvik og Porsgrunn. Bind 1. Tidlig- og mellommesolittiske lokaliteter $i$ Vestfold og Telemark, edited by Stine Melvold and Per Persson, pp. 277-308. Portal forlag, Kristiansand.

Clark, Geoffrey A.

2009 Accidents of history: Conceptual frameworks in paleoarchaeology. In Sourcebook of Paleolithic Transitions, edited by Marta Camps and Parth Chauhan, pp. 19-41. Springer, New York.

Clark, Geoffrey A., and C. Michael Barton

2017 Lithics, landscapes \& la Longue-durée - Curation \& expediency as expressions of forager mobility. Quaternary International 450:137-149. DOI:10.1016/j.quaint.2016.08.002.

Clark, Geoffrey A., and Julien Riel-Salvatore

2006 Observations on Systematics in Paleolithic Archaeology. In Transitions Before the Transition: Evolution and Stability in the Middle Paleolithic and Middle Stone Age, edited by Erella Hovers and Steven Kuhn, pp. 29-56. Springer, New York.

Crema, Enrico R.

2012 Modelling Temporal Uncertainty in Archaeological Analysis. Journal of Archaeological Method and Theory 19(3):440-461. DOI:10.1007/s10816-011-9122-3.

Damlien, Hege

2016 Eastern pioneers in westernmost territories? Current perspectives on Mesolithic hunter-gatherer large-scale interaction and migration within Northern Eurasia. Quaternary International 419:5-16. DOI:10.1016/j.quaint.2014.02.023.

Damlien, Hege, and Steinar Solheim

2018 The Pioneer Settlement of Eastern Norway. In Early Economy and Settlement in Northern Europe. Pioneering, Resource Use, Coping with Change, edited by Hans Peter Blankholm, pp. 335-367. Equinox, Sheffield.

Darmark, Kim

2018 A Cautionary Tale. Post-depositional processes affecting Stone Age sites in boreal forests, with examples from southern Norway. In The Stone Age Coastal Settlement in Aust-Agder, Southeast Norway, edited by Gaute Reitan and Lars Sundström, pp. 479-488. Cappelen Damm Akademisk, Oslo.

Dibble, Harold L.

1995 Middle Paleolithic Scraper Reduction: Background, Clarification, and Review of the Evidence to Date. Journal of Archaeological Method and Theory 2(4):299-368. DOI:10.1007/BF02229003.

Dibble, Harold L., Simon J. Holdaway, Sam C. Lin, David R. Braun, Matthew J. Douglass, Radu Iovita, Shannon P. McPherron, Deborah I. Olszewski, and Dennis Sandgathe

2017 Major Fallacies Surrounding Stone Artifacts and Assemblages. Journal of Archaeological Method and Theory 24(3):813-851. DOI:10.1007/s10816-016-9297-8. 
Eigeland, Lotte

2014 Nedre hobekk 2. Lokalitet med opphold i tidligmesolitikum og senneolitikum/jernalder. In Vestfoldbaneprosjektet. Arkeologiske undersøkelser $i$ forbindelse med ny jernbane mellom Larvik og Porsgrunn. Bind 1. Tidlig- og mellommesolittiske lokaliteter $i$ Vestfold og Telemark, edited by Stine Melvold and Per Persson, pp. 110-125. Portal forlag, Kristiansand.

2015 Maskinmennesket i steinalderen. Endring og kontinuitet i steinteknologi fram mot neolitiseringen av Øst-Norge. Unpublished $\mathrm{PhD}$ thesis, Oslo.

Eigeland, Lotte, and Guro Fossum

2014 Vallermyrene 4. En lokalitet fra nøstvetfasen med spesialisert økseproduksjon. In Vestfoldbaneprosjektet. Arkeologiske undersøkelser $i$ forbindelse med ny jernbane mellom Larvik og Porsgrunn. Bind 2. Seinmesolittiske, neolittiske og yngre lokaliteter $i$ Vestfold og Telemark, edited by Gaute Reitan and Per Persson, pp. 31-69. Portal forlag, Kristiansand.

2017 Hegna vest 4. En mellommesolittisk lokalitet med to funnkonsentrasjoner. In E18 Rugtvedt-Dørdal. Arkeologiske undersøkelser av lokaliteter fra steinalder og jernalder $i$ Bamble kommune, Telemark fylke, edited by Steinar Solheim, pp. 357-370. Portal forlag, Kristiansand.

Elster, Jon

2015 Explaining Social Behaviour: More Nuts and Bolts for the Social Sciences. Revised edition. Cambridge University Press, Cambridge.

Eymundsson, Carine S. Rosenvinge, Guro Fossum, Lucia Uchermann Koxvold, Anja Mansrud, and Axel Mjærum

2018 Axes in transformation: A bifocal view of axe technology in the Oslo fjord area, Norway, c. 9200-6000 cal BC. In The Early Settlement of Northern Europe. Transmission of Knowledge and Culture, edited by Håkon Glørstad, Kjel Knutsson, Helena Knutsson, and Jan Apel, pp. 221-229. Equinox, Sheffield.

Fossum, Guro

2017 Stokke/Polland 3. En senmesolittisk lokalitet med økseproduksjon. In E18 Rugtvedt-Dørdal. Arkeologiske undersøkelser av lokaliteter fra steinalder og jernalder $i$ Bamble kommune, Telemark fylke, edited by Steinar Solheim, pp. 413-434. Portal forlag, Kristiansand.

Frivoll, Alexander

2017 Identifisering og klassifisering av littiske råmaterialer i sør- og østnorsk steinalderforskning. Reliabilitet av visuell klassifiseringsmetode. Unpublished Master's thesis, Oslo.

Fuglestvedt, Ingrid

2007 The Ahrensburgian Galta 3 site in SW Norway. Dating, Technology and Cultural Affinity. Acta Archaeologica 78(2):87-110. DOI:10.1111/j.1600-0390.2007.00101.x.

2009 Phenomenology and the Pioneer Settlement on the Western Scandinavian Peninsula. Bricoleur Press, Lindome.

2012 The Pioneer Condition on the Scandinavian Peninsula: the Last Frontier of a 'Palaeolithic Way' in Europe. Norwegian Archaeological Review 45(1):1-29. DOI:10.1080/00293652.2012.669998.

Glørstad, Håkon

2010 The Structure and History of the Late Mesolithic Societies in the Oslo Fjord Area 6300-3800 BC. Bricoleur Press, Lindome.

2011 The Nøstvet axe. In Stone Axe Studies III, edited by Vin Davis and Mark Edmonds, pp. 21-36. Oxbow Books, Oxford.

Günther, Torsten, Helena Malmström, Emma M. Svensson, Ayça Omrak, Federico Sánchez-Quinto, Gülşah M. Kılınç, Maja Krzewińska, Gunilla Eriksson, Magdalena Fraser, Hanna Edlund, Arielle R. Munters, Alexandra Coutinho, Luciana G. Simões, Mário Vicente, Anders Sjölander, Berit Jansen Sellevold, Roger Jørgensen, Peter Claes, Mark D. Shriver, Cristina Valdiosera, Mihai G. Netea, Jan Apel, Kerstin Lidén, Birgitte Skar, Jan Storå, Anders Götherström, and Mattias Jakobsson

2018 Population genomics of Mesolithic Scandinavia: Investigating early postglacial migration routes and high-latitude adaptation. PLOS Biology 16(1):e2003703. DOI:10.1371/journal.pbio.2003703.

Hinz, Martin, Clemens Schmid, Daniel Knitter, and Carolin Tietze 
2021 oxcAAR: Interface to 'OxCal' radiocarbon calibration. $R$ package version 1.1.0.

Jaksland, Lasse

2001 Vinterbrolokalitetene - en kronologisk sekvens fra mellom-og senmesolitikum $i$ Ås, Akershus. University of Oslo, Museum of Cultural History, Oslo.

Jaksland, Lasse, and Guro Fossum

2014 Kronologiske trender i det littiske funnmaterialet. Typologi, teknologi og råstoff. In E18 Brunlanesprosjektet. Bind I. Forutsetninger og kulturhistorisk sammenstilling, edited by Lasse Jaksland and Per Persson, pp. 47-62. University of Oslo, Museum of Cultural History, Oslo.

Jaksland, Lasse, and Per Persson (editors)

2014 E18 Brunlanesprosjektet. Bind I. Forutsetninger og kulturhistorisk sammenstilling. University of Oslo, Museum of Cultural History, Oslo.

Jelinek, Arthur J.

1976 Form, function and style in lithic analysis. In Cultural Change and Continuity: Essays in Honor of James Bennett Griffin, edited by Charles E. Cleland, pp. 19-33. Academic Press, New York.

Jørgensen, Erlend Kirkeng

2017 Om vegetasjonsforstyrrelser: Konsekvenser for bevaringen av arkeologisk kontekstinformasjon i norske jordsmonn. Viking 80:157-180. DOI:10.5617/viking.5477.

Kitchel, Nathaniel, Mark S. Aldenderfer, and Randall Haas

2021 Diet, Mobility, Technology, and Lithics: Neolithization on the Andean Altiplano, 7.0-3.5 ka. Journal of Archaeological Method and Theory. DOI:10.1007/s10816-021-09525-7.

Koxvold, Lucia Uchermann, and Guro Fossum

2017 Funnbearbeiding, katalogisering og råstoffanalyser. Erfaringer fra E18 Rugtvedt-Dørdal. In E18 Rugtvedt-Dørdal. Arkeologiske undersøkelser av lokaliteter fra steinalder og jernalder $i$ Bamble kommune, Telemark fylke, edited by Steinar Solheim, pp. 85-96. Portal forlag, Kristiansand.

Kruskal, Joseph Bernard

1971 Multi-dimensional Scaling in Archaeology: Time is not the Only Dimension. In Mathematics in the Archeological and Historical Sciences, edited by F. R. Hodson, D. G. Kendall, and P Tăutu, pp. 22-38. Edinburgh University Press, Edinburgh.

Kuhn, Steven L., and Amy E. Clark

2015 Artifact densities and assemblage formation: Evidence from Tabun Cave. Journal of Anthropological Archaeology 38:8-16. DOI:10.1016/j.jaa.2014.09.002.

Lindblom, Inge

1984 Former for økologisk tilpasning i Mesolitikum, Østfold. Universitetets Oldsaksamling Årbok 1982/1983:43-86.

Lockyear, Kris

2000 Site Finds in Roman Britain: A Comparison of Techniques. Oxford Journal of Archaeology 19(4):397423. DOI:https://doi.org/10.1111/1468-0092.00118.

Manninen, Mikael A., Hege Damlien, Jan Ingolf Kleppe, Kjel Knutsson, Anton Murashkin, Anja R. Niemi, Carine S. Rosenvinge, and Per Persson

2021 First encounters in the north: cultural diversity and gene flow in Early Mesolithic Scandinavia. Antiquity 95(380):310-328. DOI:10.15184/aqy.2020.252.

Manninen, Mikael A., and Kjel Knutsson

2014 Lithic raw material diversification as an adaptive strategy-Technology, mobility, and site structure in Late Mesolithic northernmost Europe. Journal of Anthropological Archaeology 33:84-98. DOI:10.1016/j.jaa.2013.12.001.

Mansrud, Anja, and Carine Eymundsson

2016 Socialized landscapes? Lithic clusters, hearths and relocation rituals at Middle Mesolithic sites in Eastern Norway. Fennoscandia archaeologica 33:27-55.

Marwick, Ben 
2017 Computational Reproducibility in Archaeological Research: Basic Principles and a Case Study of Their Implementation. Journal of Archaeological Method and Theory 24(2):424-450. DOI:10.1007/s10816015-9272-9.

Marwick, Ben, Carl Boettiger, and Lincolc Mullen

2018 Packaging Data Analytical Work Reproducibly Using R (and Friends). The American Statistician 72(1):80-88. DOI:10.1007/s10816-015-9272-9.

Melvold, Stine, and Lotte Eigeland

2014 Langangen Vestgård 1. En boplass fra siste del av mellommesolitikum med trinnøksproduksjon og strukturer. In Vestfoldbaneprosjektet. Arkeologiske undersøkelser $i$ forbindelse med ny jernbane mellom Larvik og Porsgrunn. Bind 1. Tidlig- og mellommesolittiske lokaliteter $i$ Vestfold og Telemark, edited by Stine Melvold and Per Persson, pp. 239-276. Portal forlag, Kristiansand.

Melvold, Stine, and Per Persson (editors)

2014 Vestfoldbaneprosjektet. Arkeologiske undersøkelser i forbindelse med ny jernbane mellom Larvik og Porsgrunn. Bind 1. Tidlig- Og mellommesolittiske lokaliteter $i$ Vestfold og Telemark. Portal forlag, Kristiansand.

Melvold, Stine, Gaute Reitan, Inger Margrete Eggen, and Lotte Eigeland

2014 Utgravningsstrategi, metode og dokumentasjon. In Vestfoldbaneprosjektet. Arkeologiske undersøkelser $i$ forbindelse med ny jernbane mellom Larvik og Porsgrunn. Bind 1. Tidlig-og mellommesolittiske lokaliteter $i$ Vestfold og Telemark, edited by Stine Melvold and Per Persson, pp. 60-71. Portal forlag, Kristiansand.

Møller, Jakob J.

1987 Shoreline relation and prehistoric settlement in northern Norway. Norwegian Journal of Geography 41:45-60. DOI:http://dx.doi.org/10.1080/00291958708552171.

Nærøy, Arne Johan

2018 Early Mesolithic spatial conformity in southern Norway. Journal of Archaeological Science: Reports 18:905-912. DOI:10.1016/j.jasrep.2017.10.021.

Nash, Steven E

1996 Is Curation a Useful Heuristic? In Stone Tools: Theoretical Insights into Human Prehistory, edited by George H Odell, pp. 81-99. Springer.

Nielsen, Svein Vatsvåg

2021 A Late Mesolithic Forager Dispersal Caused Pre-Agricultural Demographic Transition in Norway. Oxford Journal of Archaeology 40(2):153-175. DOI:https://doi.org/10.1111/ojoa.12218.

Orton, David, James Morris, and Alan Pipe

2017 Catch Per Unit Research Effort: Sampling Intensity, Chronological Uncertainty, and the Onset of Marine Fish Consumption in Historic London. Open Quaternary 3(1):1. DOI:10.5334/oq.29.

Perreault, Charles

2019 The Quality of the Archaeological Record. The University of Chicago Press, Chicago \& London.

Persson, Per

2014 Prestemoen 1. En plats med ben från mellanmesolitikum. In Vestfoldbaneprosjektet. Arkeologiske undersøkelser $i$ forbindelse med ny jernbane mellom Larvik og Porsgrunn. Bind 1. Tidlig-og mellommesolittiske lokaliteter $i$ Vestfold og Telemark, edited by Stine Melvold and Per Persson, pp. 202-227. Portal forlag, Kristiansand.

$\mathrm{R}$ Core Team

2020 R: A Language and Environment for Statistical Computing. R Foundation for Statistical Computing, Vienna.

Reimer, Paula J., William E. N. Austin, Edouard Bard, Alex Bayliss, Paul G. Blackwell, Christopher Bronk Ramsey, Martin Butzin, Hai Cheng, R. Lawrence Edwards, Michael Friedrich, Pieter M. Grootes, Thomas P. Guilderson, Irka Hajdas, Timothy J. Heaton, Alan G. Hogg, Konrad A. Hughen, Bernd Kromer, Sturt W. Manning, Raimund Muscheler, Jonathan G. Palmer, Charlotte Pearson, Johannes van der Plicht, Ron W. Reimer, David A. Richards, E. Marian Scott, John R. Southon, Christian S. M. Turney, Lukas Wacker, 
Florian Adolphi, Ulf Büntgen, Manuela Capano, Simon M. Fahrni, Alexandra Fogtmann-Schulz, Ronny Friedrich, Peter Köhler, Sabrina Kudsk, Fusa Miyake, Jesper Olsen, Frederick Reinig, Minoru Sakamoto, Adam Sookdeo, and Sahra Talamo

2020 The IntCal20 Northern Hemisphere Radiocarbon Age Calibration Curve (0-55 cal kBP). Radiocarbon 62(4):725-757. DOI:10.1017/RDC.2020.41.

Reitan, Gaute

2016 Mesolittisk kronologi i Sørøst-Norge - et forslag til justering. Viking 79:23-51. DOI:10.5617/viking.3903.

Reitan, Gaute, and Per Persson (editors)

2014 Vestfoldbaneprosjektet. Arkeologiske undersøkelser $i$ forbindelse med ny jernbane mellom Larvik og Porsgrunn. Bind 2. Seinmesolittiske, neolittiske og yngre lokaliteter $i$ Vestfold og Telemark. Portal forlag, Kristiansand.

Rezek, Zeljko, Simon J. Holdaway, Deborah I. Olszewski, Sam C. Lin, Matthew Douglass, Shannon P. McPherron, Radu Iovita, David R. Braun, and Dennis Sandgathe

2020 Aggregates, Formational Emergence, and the Focus on Practice in Stone Artifact Archaeology. Journal of Archaeological Method and Theory 27(4):887-928. DOI:10.1007/s10816-020-09445-y.

Riel-Salvatore, Julien, and C. Michael Barton

2004 Late Pleistocene Technology, Economic Behavior, and Land-Use Dynamics in Southern Italy. American Antiquity 69(2):257-274. DOI:10.2307/4128419.

2007 New Quantitative Perspectives on the Middle-Upper Paleolithic Transition: The View from the Northern Mediterranean. In Early Upper Paleolithic "Transitional" Industries: New Questions, New Methods, pp. 61-73.

Riel-Salvatore, Julien, Gabriel Popescu, and C. Michael Barton

2008 Standing at the gates of Europe: Human behavior and biogeography in the Southern Carpathians during the Late Pleistocene. Journal of Anthropological Archaeology 27(4):399-417. DOI:10.1016/j.jaa.2008.02.002.

Romundset, Anders, Thomas R. Lakeman, and Fredrik Høgaas

2018 Quantifying variable rates of postglacial relative sea level fall from a cluster of 24 isolation basins in southern Norway. Quaternary Science Reviews 197:175-192. DOI:10.1016/j.quascirev.2018.07.041.

Shennan, Stephen

1997 Quantifying Archaeology. 2nd edition. Edinburgh University Press, Edinburgh.

Shott, Michael J.

1996 An Exegesis of the Curation Concept. Journal of Anthropological Research 52(3):259-280. DOI:10.1086/jar.52.3.3630085.

Shott, Michael J., and Paul Sillitoe

2005 Use life and curation in New Guinea experimental used flakes. Journal of Archaeological Science 32(5):653-663. DOI:10.1016/j.jas.2004.11.012.

Solheim, Steinar

2013 E18-lokalitetene relasjonelle struktur. In E18 Bommestad-Sky: Undersøkelse av lokaliteter fra mellommesolitikum, Larvik kommune, Vestfold fylke, edited by Steinar Solheim and Hege Damlien, pp. 276-282. Portal forlag, Kristiansand.

(editor)

2017a E18 Rugtvedt-Dørdal. Arkeologiske undersøkelser av lokaliteter fra steinalder og jernalder $i$ Bamble kommune, Telemark fylke. Portal forlag, Kristiansand.

2017b Kunnskapsstatus og faglig bakgrunn for undersøkelsene. In E18 Rugtvedt-Dørdal. Arkeologiske undersøkelser av lokaliteter fra steinalder og jernalder $i$ Bamble kommune, Telemark fylke, edited by Steinar Solheim, pp. 29-42. University of Oslo, Museum of Cultural History, Oslo.

2020 Mesolithic coastal landscapes. Demography, settlement patterns and subsistence economy in southeastern Norway. In Coastal Landscapes of the Mesolithic: Human Engagement with the Coast from the Atlantic to the Baltic Sea, edited by Almut Schülke, pp. 44-72. Routledge, London \& New York. 
Solheim, Steinar, and Hege Damlien (editors)

2013 E18 Bommestad-Sky. Undersøkelse av lokaliteter fra mellommesolitikum, Larvik kommune, Vestfold fylke. Portal forlag, Kristiansand.

Solheim, Steinar, Hege Damlien, and Guro Fossum

2020 Technological transitions and human-environment interactions in Mesolithic southeastern Norway, 11 500-6000 cal. BP. Quaternary Science Reviews 246:106-501. DOI:10.1016/j.quascirev.2020.106501.

Solheim, Steinar, and Dag Erik Færø Olsen

2013 Hovland 3. Mellommesolittisk boplass med hyttetuft. In E18 Bommestad-Sky: Undersøkelse av lokaliteter fra mellommesolitikum, Larvik kommune, Vestfold fylke, edited by Steinar Solheim and Hege Damlien, pp. 198-235. Portal forlag, Kristiansand.

Solheim, Steinar, and Per Persson

2016 Marine Adaptation in the Middle Mesolithic of South-eastern Norway. In Marine Ventures: Archaeological Perspectives on Human-Sea Relations, edited by Hein Bjartmann Bjerck, Heidi Mjelva Breivik, Silje E Fretheim, Ernesto L Piana, Birgitte Skar, Angélica M Tivoli, and Francisco J Zangrando, pp. 75-94. Equinox, Sheffield.

2018 Early and mid-holocene coastal settlement and demography in southeastern norway: Comparing distribution of radiocarbon dates and shoreline-dated sites, 8500-2000 cal. BCE. Journal of Archaeological Science: Reports 19:334-343. DOI:10.1016/j.jasrep.2018.03.007.

Sørensen, Rolf

1979 Late Weichselian deglaciation in the Oslofjord area, south Norway. Boreas 8(2):241-246. DOI:https: //doi.org/10.1111/j.1502-3885.1979.tb00806.x.

Stokke, Jo-Simon Frøshaug, and Gaute Reitan

2018 Krøgenes D7 og D10. To tidligneolittiske lokaliteter med flekkeproduksjon. In The Stone Age Coastal Settlement in Aust-Agder, Southeast Norway, edited by Gaute Reitan and Lars Sundström, pp. 309-323. Cappelen Damm Akademisk, Oslo.

Surovell, Todd A.

2009 Toward a Behavioral Ecology of Lithic Technology. The University of Arizona Press, Tucson.

Viken, Synnøve

2018 Early Mesolithic sites - are they all the same? Seventeen find concentrations from Southeast Norway in a forager-collector perspective. In The Stone Age Coastal Settlement in Aust-Agder, Southeast Norway, edited by Gaute Reitan and Lars Sundström, pp. 503-514. Cappelen Damm Akademisk, Oslo.

Villaverde, Valentín, J. Emili Aura, and C. Michael Barton

1998 The Upper Paleolithic in Mediterranean Spain: A Review of Current Evidence. Journal of World Prehistory 12(2):121-198. DOI:10.1023/A:1022332217614. 


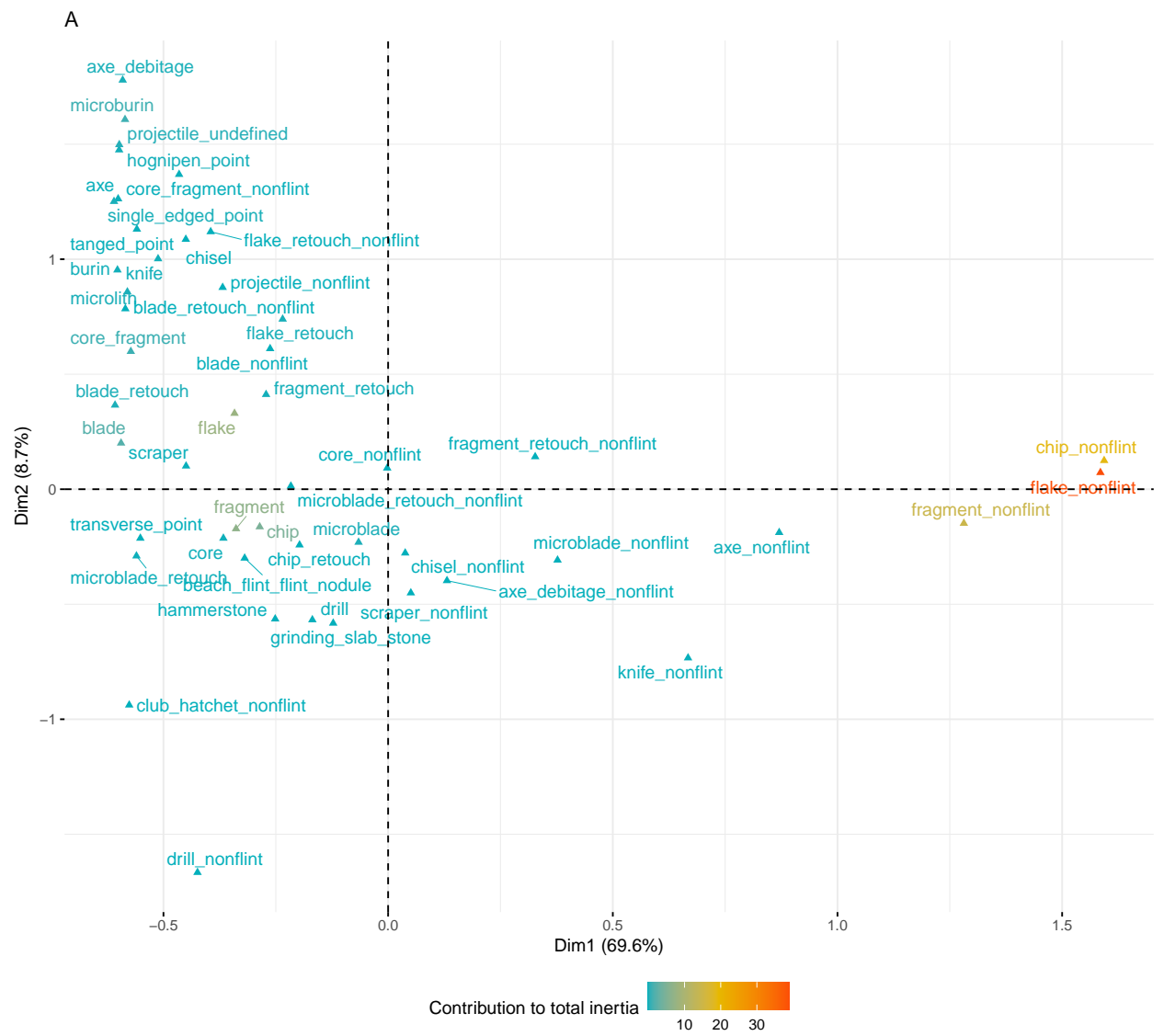

B

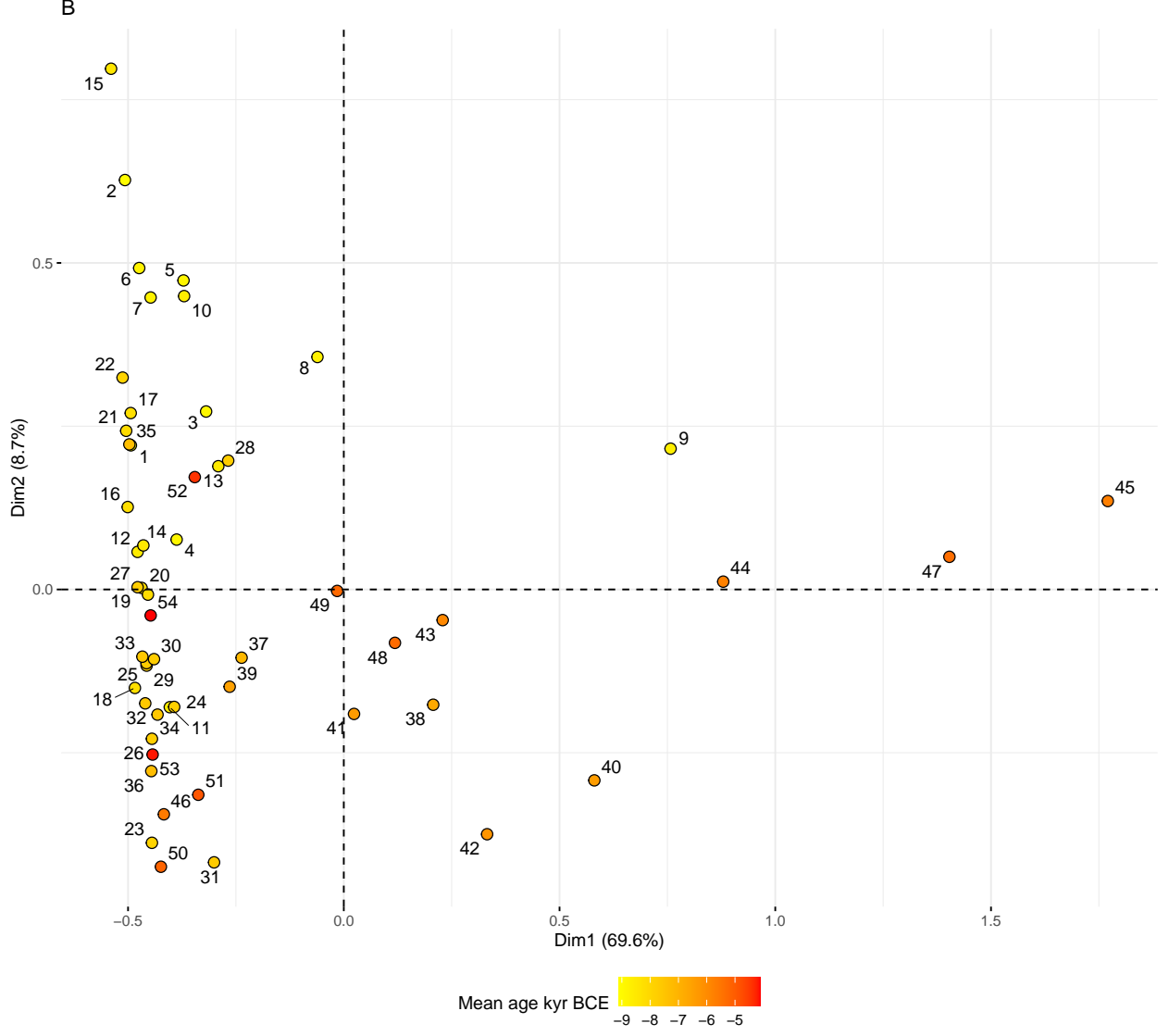

Figure 10: Correspondence analysis using all original artefact categories. A) Column plot, B) Row plot. 
A

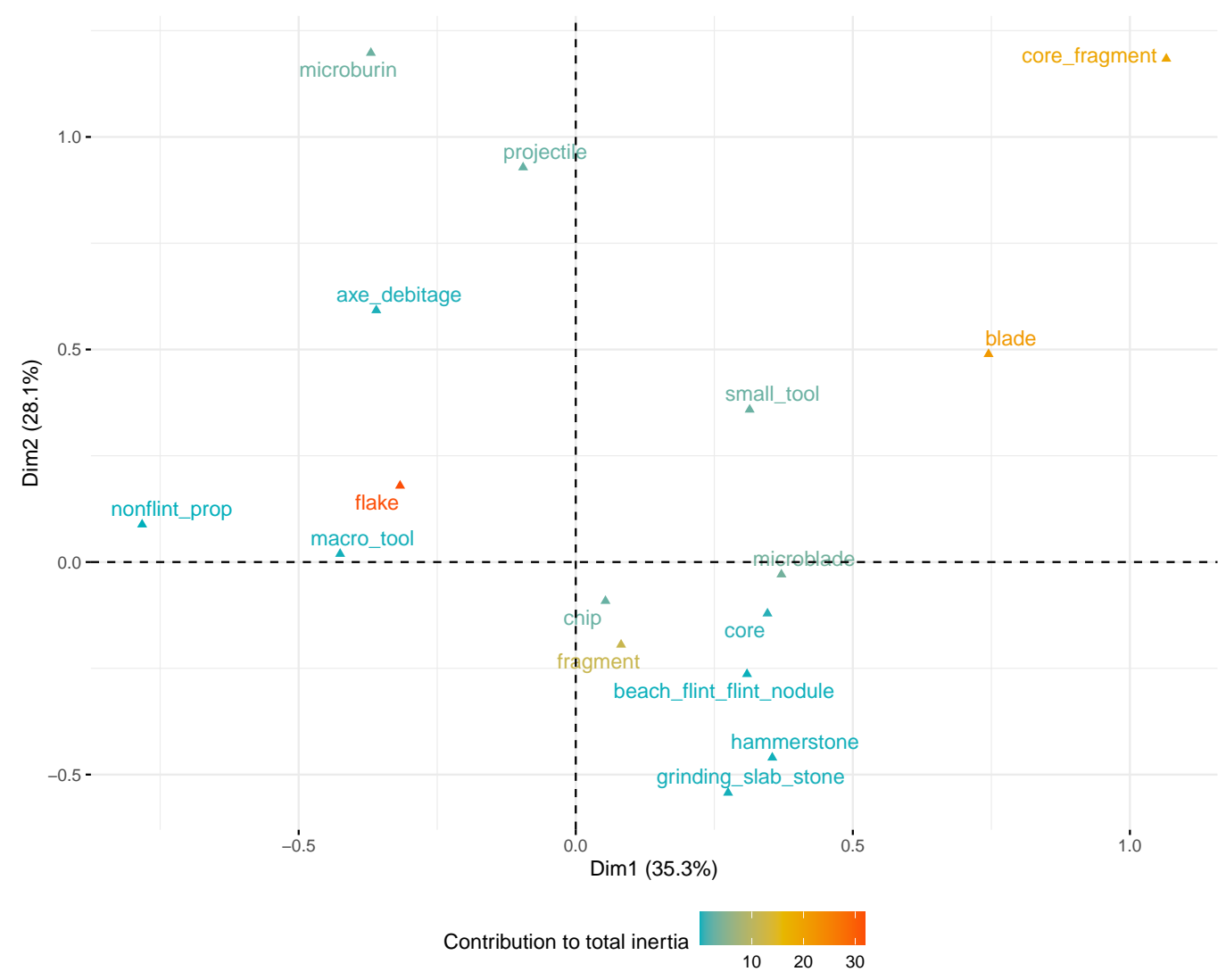

B

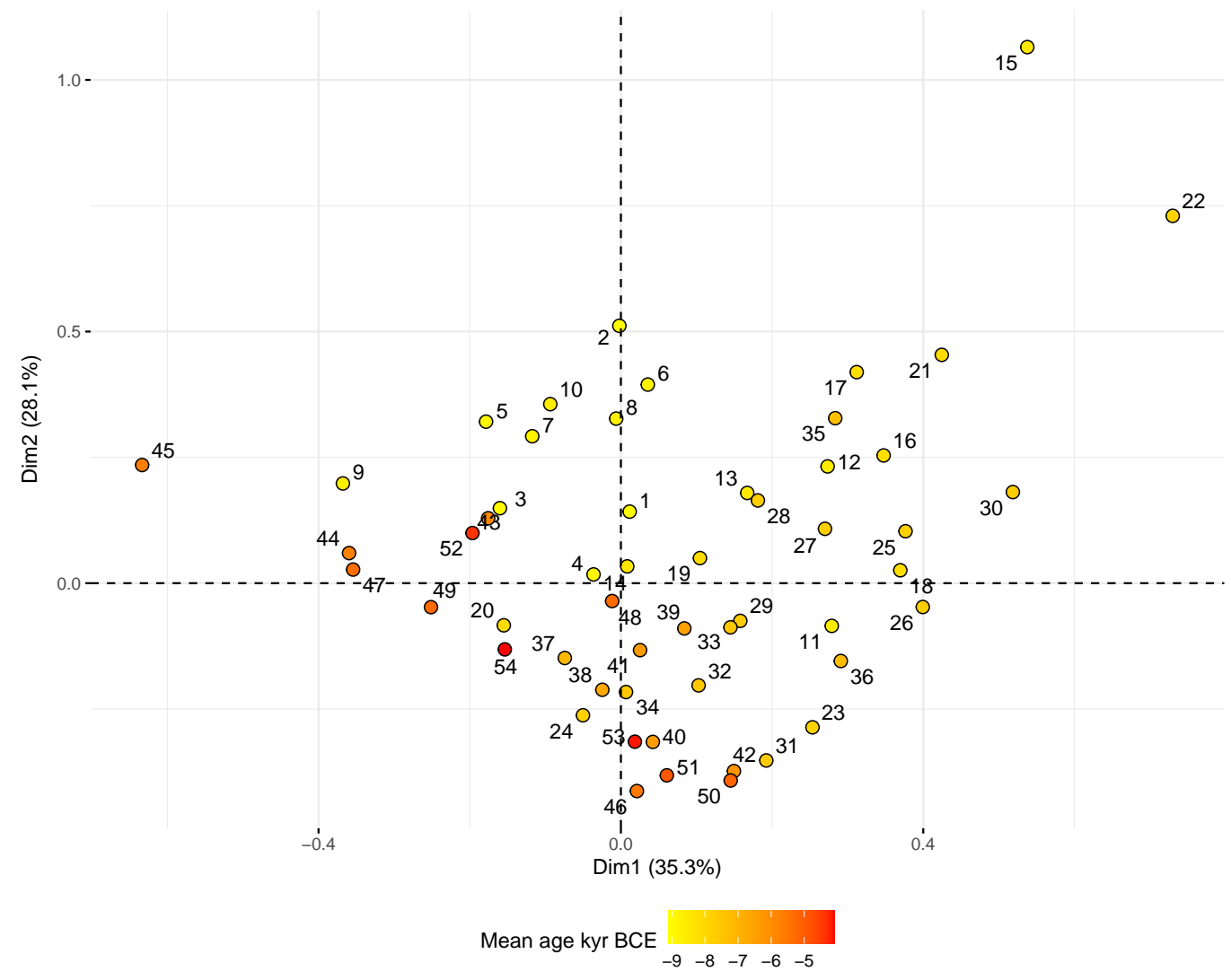

Figure 11: Correspondence analysis collapsing artefact types irrespective of raw-material and including proportion of non-flint as its own variable. A) Column plot, B) Row plot. 

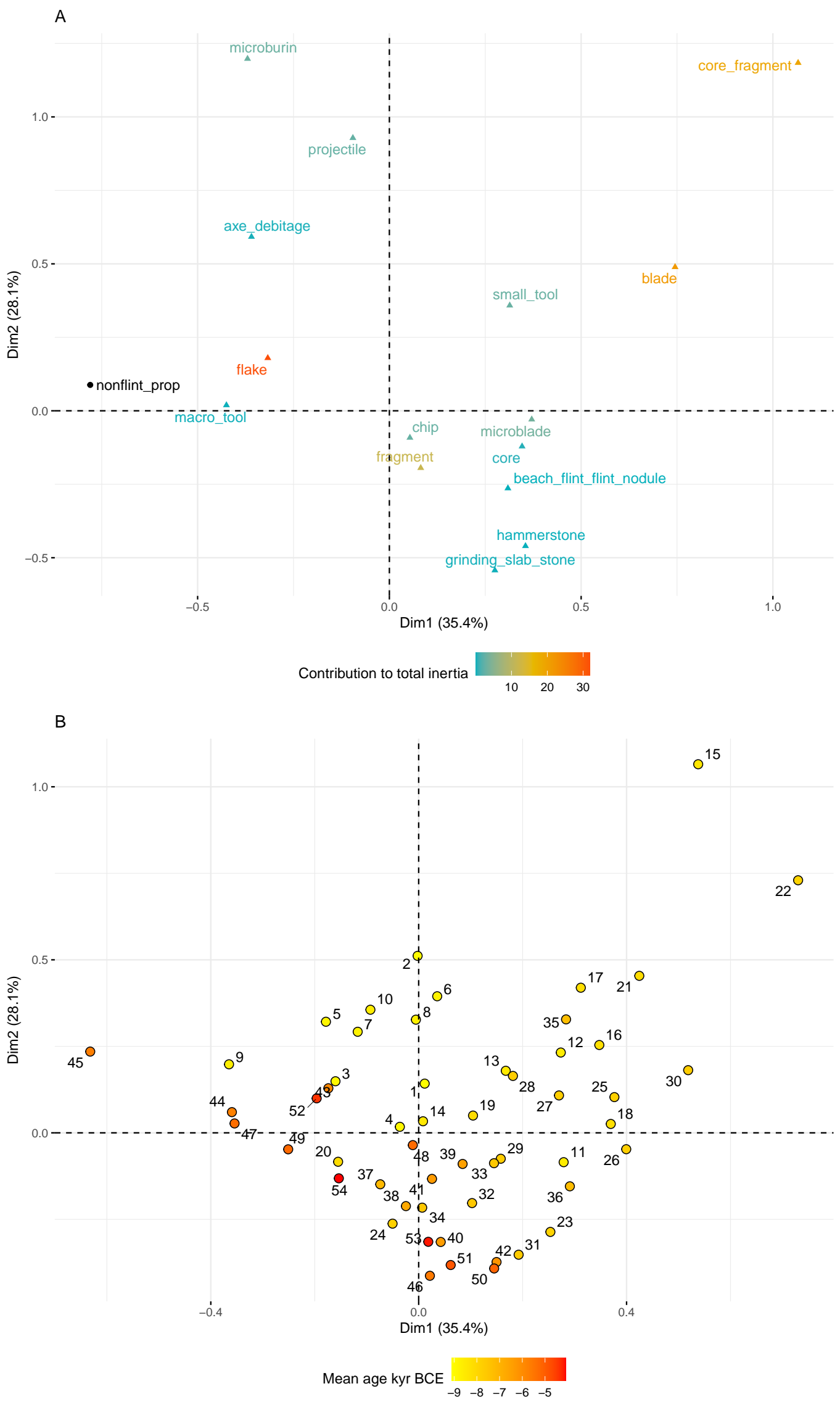

Figure 12: Same as above, only that here the proportion of non-flint is used as a supplementary column. A) Column plot, B) Row plot. The negligble difference between this CA and that above indicates that the ${ }^{30}$ flint/non-flint distinction is integrated in the different artefact types, and therefore that the effect of artefact types and raw material cannot be seperated. These plots thus hide important variability that is captured in the ones presented in the main text. 